\title{
Atmospheric Concentration, Particle-bound Content, and Dry Deposition of PCDD/Fs
}

Aerosol and Air Quality Research

\section{OPEN ACCESS}

Received: March 17, 2021

Revised: April 18, 2021

Accepted: April 19, 2021

\section{${ }^{*}$ Corresponding Authors: Kangping Cui cuikangping@hfut.edu.cn Hwey-Lin Sheu sheu@mail.ksu.edu.tw}

\section{Publisher:}

Taiwan Association for Aerosol Research

ISSN: $1680-8584$ print

ISSN: 2071-1409 online

\section{Copyright: The Author(s).} This is an open access article distributed under the terms of the Creative Commons Attribution License (CC BY 4.0), which permits unrestricted use, distribution, and reproduction in any medium, provided the original author and source are cited.

\section{Fanxuan $\mathrm{Yu}^{1}$, Kangping $\mathrm{Cui}^{{ }^{1}}{ }^{*}$, Hwey-Lin Sheu ${ }^{2 *}$, Yen-Kung Hsieh ${ }^{3}$, Xueying Tian $^{1}$}

${ }^{1}$ School of Resources and Environmental Engineering, Hefei University of Technology, Hefei 246011, China

${ }^{2}$ Department of Environmental Engineering, Kun Shan University, Tainan 71070, Taiwan

${ }^{3}$ Marine Ecology and Conservation Research Center, National Academy of Marine Research, Kaohsiung 80661, Taiwan

\section{ABSTRACT}

In this study, the atmospheric total-PCDD/Fs-WHO $2005-T E Q$ concentrations, gas-particle partitioning, $\mathrm{PM}_{2.5}$ concentration, $\mathrm{PM}_{2.5}$-bound total $\mathrm{PCDD} / \mathrm{Fs}-\mathrm{WHO}_{2005}-\mathrm{TEQ}$ content and dry deposition flux in Shanghai and Nanjing were investigated from 2018-2020. In Shanghai, the total $\mathrm{PCDD} / \mathrm{Fs}-\mathrm{WHO}_{2005}-\mathrm{TEQ}$ concentration dropped from $0.0291 \mathrm{pg}-\mathrm{WHO}_{2005}-\mathrm{TEQ} \mathrm{m}^{-3}$ from 2018-2019 to 0.0250 pg- $\mathrm{WHO}_{2005}$-TEQ $\mathrm{m}^{-3}$ in 2020, while in Nanjing, it dropped from $0.0423 \mathrm{pg}-\mathrm{WHO}_{2005}-$ TEQ $\mathrm{m}^{-3}$ to $0.0338 \mathrm{pg}-\mathrm{WHO}_{2005}-\mathrm{TEQ} \mathrm{m}^{-3}$. The average concentrations of PCDD/Fs-WHO $2005-\mathrm{TEQ}$ in spring and winter in Shanghai and Nanjing were $47.6 \%$ and $53.8 \%$ higher than those in summer, respectively. From 2018-2019, the average particle phase fractions of total-PCDD/Fs-WHO ${ }_{2005}-\mathrm{TEQ}$ in Shanghai and Nanjing were $50.3 \%$ and $57.5 \%$, respectively, while in 2020, they were $47.8 \%$ and $55.1 \%$, respectively. From 2018-2019, the average $\mathrm{PM}_{2.5}$-bound total PCDD/Fs-WHO 2005 -TEQ content was 0.342 and $0.493 \mathrm{ng}-\mathrm{WHO}_{2005}-\mathrm{TEQ} \mathrm{g}^{-1}$ in Shanghai and Nanjing, respectively, while in 2020, it was 0.312 and 0.489 ng- $\mathrm{WHO}_{2005}-\mathrm{TEQ} \mathrm{g}^{-1}$, respectively. In Shanghai and Nanjing, the average $\mathrm{PM}_{2.5^{-}}$ bound total PCDD/Fs-WHO 2005 -TEQ content in spring and winter was $77.5 \%$ and $73.2 \%$ higher than that in summer, respectively. From 2018-2019, the dry deposition flux of total-PCDD/Fs-WHO2005-

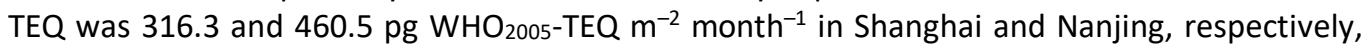
while in 2020, it was 272.5 and $368.4 \mathrm{pg} \mathrm{WHO}_{2005}-\mathrm{TEQ} \mathrm{m}^{-2} \mathrm{month}^{-1}$, respectively. The average dry deposition flux of total-PCDD/Fs- $\mathrm{WHO}_{2005}$-TEQ in spring and winter was $47.6 \%$ and $53.8 \%$ higher than that summer in Shanghai and Nanjing, respectively. The above results indicate that COVID-19 in 2020 had a positive effect on air quality improvement in PCDD/Fs. On average, more than 98.88\% of the total PCDD/Fs-WHO $\mathrm{WH}_{200}$-TEQ dry deposition flux was primarily contributed by the particle phase. This was attributed to the fact that dry deposition of particle phase PCDD/Fs was mainly due to gravitational settling accompanied by higher dry deposition velocities, while the gas phase PCDD/Fs were deposited mostly by diffusion at a lower dry deposition velocity.

Keywords: PCDD/Fs, $\mathrm{PM}_{2.5}$, Particle-bound, Phase distribution, Dry deposition

\section{INTRODUCTION}

PCDD/Fs are common persistent organic pollutants (POPs) in the environment. They are the general name for polychlorinated dibenzo-p-dioxins (PCDDs) and polychlorinated dibenzofurans (PCDFs) (Alcock et al., 1996). In addition, PCDD/Fs have strong thermal stability, high decomposition temperatures above $700^{\circ} \mathrm{C}$, are extremely insoluble in water, and are soluble in most organic solvents (Wielgosiński et al., 2011). There are 210 homologous PCDD/F isomers, of which 17 (2, 3, 7 , and 8 are all replaced by chlorine atoms) are considered to be harmful to human health (Li et al., 2016). The sources of PCDD/Fs in nature are mainly volcanic eruptions and forest fires, and dioxins can also be produced by human activities, such as burning of waste, chemical manufacturing, metal 
smelting and automobile exhaust (Qiu et al., 2020). PCDD/Fs in the environment can enter the biological system through respiration, absorption and ingestion.

The concept of Toxic Equivalent Quantity (TEQ) is often used in the international toxicity evaluation of PCDD/Fs, which is expressed by the amount of 2,3,7, and 8-TCDD (Hsieh et al., 2018). PCDD/Fs are highly toxic and can exist in environmental media for a long time (Wang et al., 2020). Moreover, $\mathrm{PM}_{2.5}$ can be used as the transmission medium for long-distance transport through the atmosphere and ocean currents and seriously affects human health. The elimination of PCDD/Fs occurs mainly through migration, diffusion and deposition, which is closely related to the distribution of the gas-solid phase and temperature in the atmospheric environment. The gas phase can be removed from the environment by photodegradation and $\mathrm{OH}$ radical reactions, while the particle phase mainly entered the soil and aquatic environment through sedimentation. (Koester et al., 1992; Lohmann et al., 2007).

Particulate matter (PM) is one of the most important components of air pollution in China. Particulate matter is a type of aerosol. It refers to solid or liquid particles in the atmosphere and can be further classified according to its size (Ghosh et al., 2014). PM2.5 is a type of fine particulate matter with a diameter of less than $2.5 \mu \mathrm{m}$. $\mathrm{PM}_{2.5}$ is also known as a fine particulate that can directly enter the lungs. It is used as the main pollutant index that characterizes the ambient air quality (Chow et al., 2015). Increases in $\mathrm{PM}_{2.5}$ concentrations haves significantly reduced urban visibility, worsened climate conditions, and seriously damaged the environment (Menon et al., 2002). High concentrations of $\mathrm{PM}_{2.5}$ are also harmful to human health. Studies have shown that the risk of acute lower respiratory tract infection increases by $1.12 \%$ for every $10 \mu \mathrm{g} \mathrm{m}^{-3}$ increase in the annual PM2.5 concentration (Mehta et al., 2013; Xing et al., 2016). At present, aerosols in cities are mainly emitted directly from human activities such as combustion and automobile exhaust (Kong et al., 2014).

In this study, the concentration, gas-particle partitioning and $\mathrm{PM}_{2.5}$-bound content of totalPCDD/Fs-WHO ${ }_{2005}-\mathrm{TEQ}, \mathrm{PM}_{2.5}$ concentrations, and dry deposition of total-PCDD/Fs-WHO $2005-\mathrm{TEQ}$ in two cities (Shanghai and Nanjing) in the south of China from 2018 to 2020 were investigated, compared and discussed.

\section{METHODS}

The air quality from 2018 to 2020 in Shanghai and Nanjing was investigated, including total$\mathrm{PCDD} / \mathrm{Fs}-\mathrm{WHO}_{2005}-\mathrm{TEQ}$ concentrations, $\mathrm{PCDD} / \mathrm{F}$ gas-particle partitioning, $\mathrm{PM}_{2.5}$ concentration, $\mathrm{PM}_{2.5}$-bound total PCDD/Fs-WHO 2005 -TEQ content and dry deposition of total-PCDD/Fs-WHO ${ }_{2005}$ TEQ.

Shanghai City is located in the Yangtze River Delta region, at a $120^{\circ} 52^{\prime}-122^{\circ} 12^{\prime}$ east longitude and a $30^{\circ} 40^{\prime}-31^{\circ} 53^{\prime}$ north latitude. It has a subtropical monsoon climate. The annual temperature in Shanghai ranges between 2.0 and 34 and averages $17.6^{\circ} \mathrm{C}$; the annual average sunshine totals approximately 1,663 hours, and the annual average precipitation is $1,173.4 \mathrm{~mm}$. More than $60 \%$ of the annual rainfall is concentrated into the flood season, which runs from May to September.

Nanjing is located in the southwest of Jiangsu Province, at a $118^{\circ} 22^{\prime \prime}-119^{\circ} 14^{\prime \prime}$ east longitude and a $31^{\circ} 14^{\prime}-32^{\circ} 37^{\prime}$ north latitude. It has a humid climate and is located in the northern subtropics. The annual average temperature in Nanjing ranges between -2.0 and 33 and averages $15.4^{\circ} \mathrm{C}$. The annual average sunshine is approximately 1,944 hours, and the annual average precipitation is $1,106.5 \mathrm{~mm}$. More than $60 \%$ of the annual rainfall is concentrated in the rainy season, which runs from May to September.

\subsection{PCDD/F Concentration}

In the absence of measured data, the concentration of PCDD/Fs can be simulated using a regression analysis. For the purposes of this study, two regression analysis equations were selected, for which the results were averaged. The two equations are as follows (Wang et al., 2010; Huang et al., 2011):

$Y_{1}=0.0138 X \pm 0.0472$ 
$Y_{2}=0.0117 X-0.021$

where $Y_{1}$ and $Y_{2}$ represent the concentration of total PCDD/Fs, and $X$ represents the concentration of $\mathrm{PM}_{10}$ in the urban atmosphere.

The goodness-of-fit of regression equation is $R^{2}=0.9855$ (Suryani et al., 2015; Lee et al., 2016). The results indicated good reliability in terms of prediction and goodness of fit. In this study, the regression was used to obtain the PCDD/F concentration. The concentration of total PCDD/Fs was obtained from the mean value of $Y_{1}$ and $Y_{2}$, and the PCDD/Fs were analyzed and discussed by combining the meteorological data for the local cities.

\subsection{Gas-Particle Partitioning}

The gas and particle partitioning of PCDD/Fs were evaluated by multiplying the gas-particle distribution by the total concentration of PCDD/Fs. The gas-particle partitioning constant $\left(K_{p}\right)$ is calculated as follows (Yamasaki et al., 1982; Pankow et al., 1992):

$K_{p}=\frac{F / T S P}{A}$

where TSP represents the concentration of total suspended particulate matter. $\left(\mu \mathrm{g} \mathrm{m}^{-3}\right) ; \mathrm{F}$ represents the concentration of the compounds of interest bound to particles $\left(\mathrm{pg} \mathrm{m}^{-3}\right)$, and $A$ represents the gaseous concentration of the compound of interest $\left(\mathrm{pg} \mathrm{m}^{-3}\right)$.

Plotting log $\mathrm{K}_{\mathrm{p}}$ against the logarithm of the subcooled liquid vapor pressure, $\mathrm{PL}^{0}$, gives (Hung et al., 2002):

$\log K_{p}=m_{r} \times \log P_{L}^{0}+b_{r}$

where $\mathrm{PL}^{0}$ represents the subcooled liquid vapor pressure $(\mathrm{Pa}) ; \mathrm{m}_{\mathrm{r}}$ represents the cited slope, -1.29 , and $b_{r}$ represents the cited $y$-intercept, -7.2 (Chao et al., 2004).

In this study, the $\mathrm{P}_{\mathrm{L}}{ }^{0}$ of $\mathrm{PCDD} /$ Fs is correlated with the gas chromatographic retention indexes (GC-RI) on a nonpolar (DB-5) GC-column using $p, p^{\prime}$-DDT as a reference standard.

$\log P_{L}^{0}=\frac{-1.34(R I)}{T}+1.67 \times 10^{-3}(R I)-\frac{1320}{T}+8.087$

where RI represents the gas chromatographic retention indexes (Donnelly et al., 1987), and T represents the ambient temperature (K).

\subsection{Dry Deposition Flux of PCDD/Fs}

The dry sedimentation flux is a combination of the diffusion of gaseous matter and the sedimentation of granular matter.

$F_{T}=F_{g}+F_{p}$

$C_{T} \times V_{d, T}=C_{g} \times V_{d, g}+C_{p} \times V_{d, p}$

where $\mathrm{F}_{\mathrm{T}}$ represents the total dry deposition flux (pg WHO $\mathrm{WH}_{205}-\mathrm{TEQ} \mathrm{m}^{-2}$ month $^{-1}$ ); $\mathrm{F}_{\mathrm{g}}$ : represents the diffusion of gaseous matter producing dry deposition flux (pg $\mathrm{WHO}_{2005}-\mathrm{TEQ} \mathrm{m}^{-2} \mathrm{month}^{-1}$ ); $\mathrm{F}_{\mathrm{p}}$ represents the gravitational settling of particulate matter producing dry deposition flux (pg $\mathrm{WHO}_{2005}$-TEQ $\mathrm{m}^{-2}$ month $^{-1}$ ); $\mathrm{C}_{\mathrm{T}}$ represents the total concentration of PCDD/Fs in the atmosphere $\left(\mathrm{pg} \mathrm{m}^{-3}\right) ; \mathrm{V}_{\mathrm{d}, \mathrm{T}}$ represents the dry deposition rate of PCDD/Fs, $0.42 \mathrm{~cm} \mathrm{~s}^{-1}$ (Shih et al., 2006); $\mathrm{Cg}_{\mathrm{g}}$ represents the calculated concentration of PCDD/Fs in the gas phase $\left(\mathrm{pg} \mathrm{m}^{-3}\right) ; V_{d, g}$ represents the dry deposition rate of PCDD/Fs in gas phase, $0.01 \mathrm{~cm} \mathrm{~s}^{-1}$ (Sheu et al., 1996); $C_{p}$ represents the calculated concentration of PCDD/Fs in the particle phase $\left(\mathrm{pg} \mathrm{m}^{-3}\right)$, and $\mathrm{V}_{\mathrm{d}, \mathrm{p}}$ represents the dry deposition rate of PCDD/Fs in the particle phase $\left(\mathrm{cm} \mathrm{s}^{-1}\right)$. 


\section{RESULTS AND DISCUSSION}

\subsection{Total-PCDD/Fs-WHO 2005 -TEQ Concentration}

The total-PCDD/Fs-WHO ${ }_{2005}$-TEQ concentrations were calculated based on the combination of the PCDD/Fs mass concentration and the toxicity equivalence factor (TEF) following the World Health Organization (WHO) guidelines. The average monthly total-PCDD/Fs- $\mathrm{WHO}_{2005}-\mathrm{TEQ}$ concentrations in Shanghai and Nanjing during 2018-2020 are shown in Fig. 1.

As shown in Fig. 1(a), the total-PCDD/Fs-WHO 2005 -TEQ concentrations in Shanghai in the four seasons (spring, summer, autumn, and winter) of 2018 ranged between 0.0326 and 0.0472 , between 0.0150 and 0.0202 , between 0.0243 and 0.0285 , and between 0.0284 and $0.0362 \mathrm{pg}-\mathrm{WHO}_{2005}-$ TEQ $\mathrm{m}^{-3}$, and averaged $0.0388,0.0174,0.0271$, and $0.0329 \mathrm{pg}-\mathrm{WHO}_{2005}-\mathrm{TEQ} \mathrm{m}^{-3}$, respectively. $\ln 2018$ in Shanghai, the average total-PCDD/Fs-WHO ${ }_{2005}-\mathrm{TEQ}$ concentration $\left(0.0358 \mathrm{pg}-\mathrm{WHO}_{2005}-\mathrm{TEQ} \mathrm{m}^{-3}\right)$ in spring and winter was $51.4 \%$ higher than that in summer $\left(0.0174 \mathrm{pg}-\mathrm{WHO}_{2005}-\mathrm{TEQ} \mathrm{m}^{-3}\right)$, indicating that the lowest value usually occurs in summer. As can be seen, in summer, due to an increase in the ambient temperature in Shanghai, the concentration of PCDD/Fs in the gas phase also increases. In winter, with the decrease in the temperature, the atmospheric density increases, and part of the PCDD/Fs in the gas phase is transferred to the particle phase. This may also be related to coal combustion and atmospheric inversion in winter, where the temperature inversion indicates that the air temperature rises with an increase in altitude, which promotes the accumulation of particulate
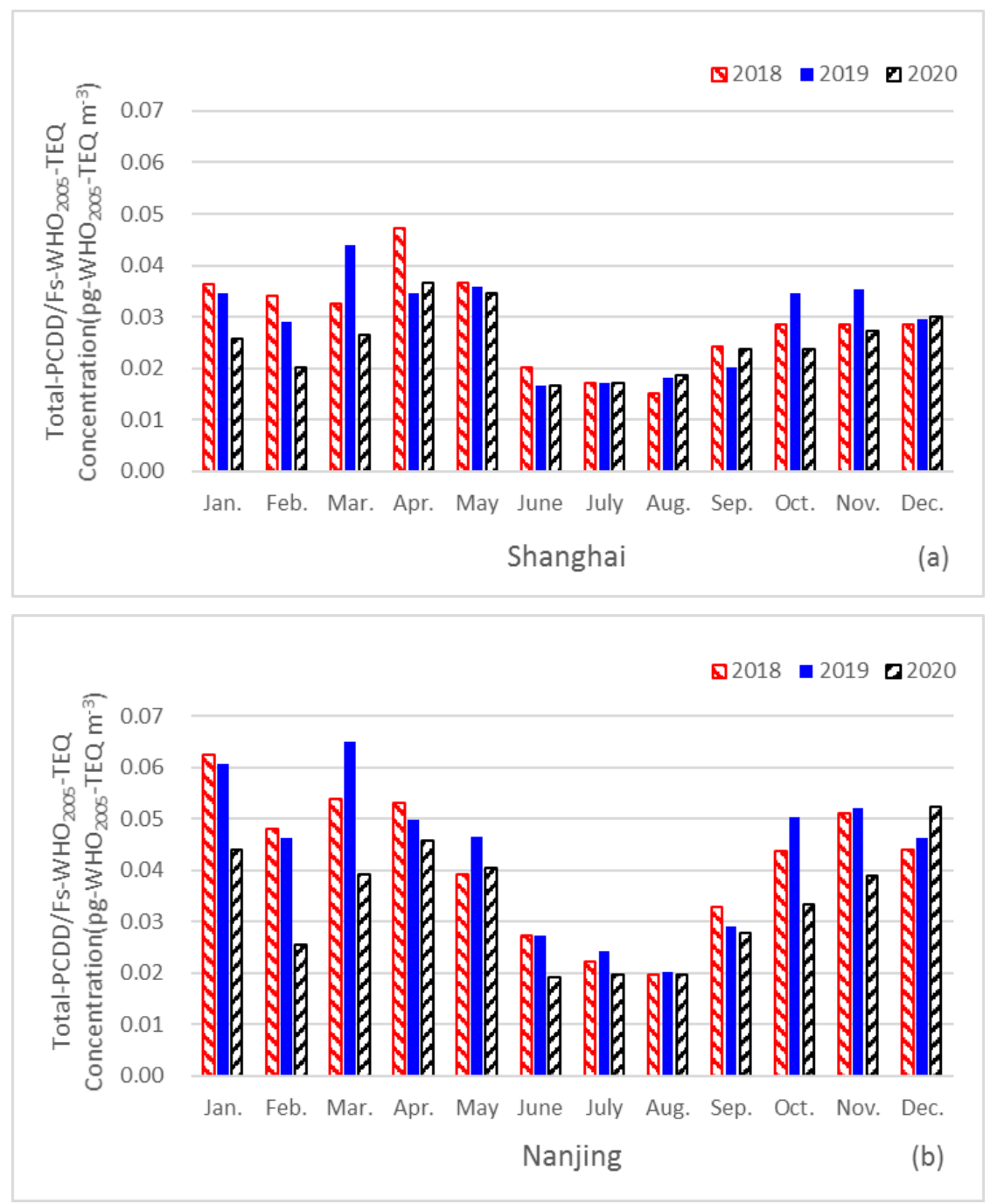

Fig. 1. Monthly total-PCDD/Fs-WHO 2005 -TEQ concentrations in Shanghai and Nanjing in 2018, 2019 , and 2020, respectively. 
matter on the ground and causes significant air pollution. In addition, according to the monthly PM2.5 concentration and total-PCDD/Fs-WHO $\mathrm{WH}_{205}$-TEQ concentration comparison, it was found that a higher $\mathrm{PM}_{2.5}$ concentration was highly correlated with a higher total-PCDD/Fs-WHO $\mathrm{W}_{2005}-\mathrm{TEQ}$ concentration.

In Shanghai, in the four seasons (spring, summer, autumn, and winter) of 2019, total-PCDD/Fs$\mathrm{WHO}_{2005}$-TEQ concentrations ranged from 0.0345 to 0.0438 , from 0.0165 to 0.0181 , from 0.0200 to 0.0352 , and from 0.0290 to $0.0346 \mathrm{pg}-\mathrm{WHO}_{2005}-\mathrm{TEQ} \mathrm{m}^{-3}$, and averaged 0.0381, 0.0172, 0.0299, and 0.0310 pg- $\mathrm{WHO}_{2005}-\mathrm{TEQ} \mathrm{m}^{-3}$, respectively. In 2019, the average total-PCDD/Fs-WHO $2005-\mathrm{TEQ}$ concentration $\left(0.0346 \mathrm{pg}-\mathrm{WHO}_{2005}-\mathrm{TEQ} \mathrm{\textrm {m } ^ { - 3 }}\right)$ in spring and winter was $50.1 \%$ higher than that in summer $\left(0.0172\right.$ pg-WHO $\left.2005-\mathrm{TEQ} \mathrm{m}^{-3}\right)$.

The concentrations in Shanghai in 2020 (spring, summer, autumn, and winter) ranged from 0.0266-0.0365, 0.0165-0.0186, 0.0237-0.0273, and 0.0201-0.0301 pg-WHO $2005-\mathrm{TEQ} \mathrm{m}^{-3}$, with an average of $0.0326,0.0174,0.0249$, and 0.0253 pg- $\mathrm{WHO}_{2005}-\mathrm{TEQ} \mathrm{m}^{-3}$, respectively. In 2020 , the average total-PCDD/Fs-WHO $\mathrm{WH}_{2005}-\mathrm{TEQ}$ concentrations $\left(0.0289 \mathrm{pg}-\mathrm{WHO}_{2005}-\mathrm{TEQ} \mathrm{m}^{-3}\right)$ in spring and winter were $39.8 \%$ higher than that of summer $\left(0.0174 \mathrm{pg}-\mathrm{WHO}_{2005}-\mathrm{TEQ} \mathrm{m}^{-3}\right)$. This was down $15.3 \%, 12.8 \%$, and $20.9 \%$ from the same period in the spring, autumn, and winter of 2018-2019, respectively, while it rose by $0.5 \%$ in the summer. In addition, the average total-PCDD/Fs- $\mathrm{WHO}_{2005}$ TEQ concentrations in 2018 and 2019 was 0.0290 and $0.0291 \mathrm{pg}-\mathrm{WHO}_{2005}-\mathrm{TEQ} \mathrm{\textrm {m } ^ { - 3 }}$, respectively. In 2020, the average concentration was $0.0250 \mathrm{pg}-\mathrm{WHO}_{2005}-\mathrm{TEQ} \mathrm{m}^{-3}$, which was significantly lower than that in 2018-2019. Based on the data from Shanghai in the last three years, the average concentration for 2020 was $13.9 \%$ lower than the average for 2018-2019. Shanghai began to implement strict epidemic prevention measures in February 2020, and the concentration of PCDD/Fs in February 2020 was 36.3\% lower than that in 2018-2019. Under the control measures, factories were closed, and employees were on leave, so industrial waste gas and traffic emissions were significantly reduced, and air quality was significantly improved.

As shown in Fig. 1(b), the total-PCDD/Fs-WHO 2005 -TEQ concentrations in Nanjing in the four seasons (spring, summer, autumn, and winter) in 2018 ranged between 0.0392 and 0.0538 , between 0.0196 and 0.0274 , between 0.0328 and 0.0510 , and between 0.0440 and $0.0624 \mathrm{pg}-\mathrm{WHO}_{2005}$ TEQ $\mathrm{m}^{-3}$, and averaged $0.0487,0.0231,0.0425$, and 0.0515 pg-WHO $2005-\mathrm{TEQ} \mathrm{m}^{-3}$, respectively. In 2018, the average total-PCDD/Fs-WHO $2005-\mathrm{TEQ}$ concentrations $\left(0.0501 \mathrm{pg}-\mathrm{WHO}_{2005}-\mathrm{TEQ} \mathrm{m}^{-3}\right)$ in spring and winter were $53.9 \%$ higher than those in summer $\left(0.0231 \mathrm{pg}-\mathrm{WHO}_{2005}-\mathrm{TEQ} \mathrm{\textrm {m } ^ { - 3 }}\right)$, indicating that high temperatures can vaporize PCDD/Fs from the particle phase to the gas phase. In the four seasons (spring, summer, autumn, and winter) of 2019, total-PCDD/Fs-WHO $\mathrm{W}_{2005}$-TEQ concentrations ranged from 0.0465 to 0.0651 , from 0.0202 to 0.0274 , from 0.0291 to 0.0522 , and from 0.0463 to 0.0607 pg-WHO $\mathrm{WH}_{205}$-TEQ $\mathrm{m}^{-3}$, and averaged $0.0538,0.0239,0.0439$, and $0.0511 \mathrm{pg}-\mathrm{WHO}_{2005}-\mathrm{TEQ} \mathrm{m}^{-3}$, respectively. In 2019, the average total-PCDD/Fs-WHO 2005 -TEQ concentrations $\left(0.0524\right.$ pg- $\mathrm{WHO}_{2005-}$ TEQ $\left.\mathrm{m}^{-3}\right)$ in spring and winter were $54.3 \%$ higher than those in summer $\left(0.0239 \mathrm{pg}-\mathrm{WHO}_{2005}-\mathrm{TEQ} \mathrm{m}^{-3}\right)$. Those during 2020 were ranged from $0.0392-0.0458,0.0191-0.0196,0.0279-0.0388$, and $0.0256-$ 0.0524 pg-WHO $\mathrm{W}_{2005}$-TEQ $\mathrm{m}^{-3}$, and averaged $0.0418,0.0195,0.0334$, and $0.0407 \mathrm{pg}-\mathrm{WHO}_{2005}-\mathrm{TEQ} \mathrm{m}^{-3}$, respectively. In 2020, the average total-PCDD/Fs-WHO2005-TEQ concentrations $\left(0.0413\right.$ pg- $\mathrm{WHO}_{2005-}$ TEQ $\left.\mathrm{m}^{-3}\right)$ in spring and winter were $52.8 \%$ higher than those in summer $\left(0.0195 \mathrm{pg}-\mathrm{WHO}_{2005}-\mathrm{TEQ} \mathrm{m}^{-3}\right)$ and were $18.4 \%$ (spring), $17.2 \%$ (summer), $22.7 \%$ (autumn), and 20.6\% (winter) lower than those from 2018-2019. In addition, the average total-PCDD/Fs-WHO $2005-T E Q$ concentrations in 2018 and 2019 were 0.0414 and 0.0432 pg- $\mathrm{WHO}_{2005}-\mathrm{TEQ} \mathrm{m}^{-3}$, respectively. In 2020, the average concentration was 0.0338 pg- $\mathrm{WHO}_{2005}$-TEQ $\mathrm{m}^{-3}$, which was $18.3 \%$ and $21.6 \%$ lower than those in 2018 and 2019, respectively. Based on data from Nanjing in the last three years, the average concentration for 2020 was $20.0 \%$ lower than that the average for the period 2018-2019. Nanjing began to implement strict epidemic prevention measures in February 2020, and the concentration of PCDD/Fs in February 2020 was $45.5 \%$ lower than the average for the period 2018-2019. Because Nanjing's air quality was worse than that in Shanghai, the city needs a big improvement.

Table 1 shows total-PCDD/Fs-WHO 2005 -TEQ concentrations in atmospheric environments in some countries and cities globally. The results of this study were in a similar range compared with those found in other countries.

\subsection{Gas-Particle Partitioning of PCDD/Fs}

The gas-particulate distribution of PCDD/Fs plays an important role in the wet and dry deposition 
Table 1. Total-PCDD/Fs-WHO $2005-\mathrm{TEQ}$ concentration range in some regions in the world.

\begin{tabular}{|c|c|c|c|}
\hline Country & City & $\begin{array}{l}\text { PCDD/Fs-WHO } 2005-T E Q \text { Con. } \\
\left(\mathrm{pg}-\mathrm{WHO}_{2005}-\mathrm{TEQ} \mathrm{m}^{-3}\right)\end{array}$ & Reference \\
\hline Germany & Berlin & $0.02-0.40$ & Christman et al., 1989 \\
\hline Sweden & Stockholm & $0.003-0.024$ & Broman et al., 1991 \\
\hline Italy & Rome & $0.05-0.28$ & Turrio-Baldassarri et al., 1994 \\
\hline England & Manchester & $0.03-0.22$ & Coleman et al., 1997 \\
\hline England & London & $0.07-0.20$ & Coleman et al., 1997 \\
\hline Portugal & Oporto & $0.02-0.55$ & Coutinho et al., 2001 \\
\hline Korea & - & $0.17-0.88$ & Park and Kim, 2002 \\
\hline Greece & Thessaloniki & $0.12-0.40$ & Mandalakis et al., 2002 \\
\hline China & Hong Kong & $0.02-0.43$ & Sin et al., 2002 \\
\hline USA & Houston & $0.009-0.032$ & Correa et al., 2004 \\
\hline Brazil & Sao Paulo & $0.05-0.75$ & de Assunção et al., 2005 \\
\hline Spain & Catalonia & $0.005-1.20$ & Abad et al., 2007 \\
\hline Belgium & Flanders & $0.02-0.38$ & Zhou et al., 2014 \\
\hline USA & Phoenix & $0.09-0.45$ & Correa et al., 2004 \\
\hline \multirow[t]{4}{*}{ China } & Wuhu & $0.021-0.085$ & Wang et al., 2018 \\
\hline & Chongqing & $0.030-0.059$ & Xing et al., 2017 \\
\hline & Shanghai & $0.015-0.047$ & This study, 2021 \\
\hline & Nanjing & $0.019-0.065$ & This study, 2021 \\
\hline
\end{tabular}

removal rate. The gas-particle distribution of semi-volatile organic compounds is affected by the temperature, the nature of the particulate matter, and its interaction with environmental organic matter (Pankow et al., 1987). Monthly minimum, maximum, and average temperatures in Shanghai and Nanjing during the period 2018-2020 are shown in Table 2. The average monthly maximum temperatures in Shanghai in 2018,2019 , and 2020 were $33.0^{\circ} \mathrm{C}, 32.0^{\circ} \mathrm{C}$, and $34.0^{\circ} \mathrm{C}$, respectively. The average monthly minimum temperatures were $2.0^{\circ} \mathrm{C}, 4.0^{\circ} \mathrm{C}$, and $4.0^{\circ} \mathrm{C}$, respectively, and the annual average temperatures were $18.0^{\circ} \mathrm{C}, 17.5^{\circ} \mathrm{C}$, and $18.0^{\circ} \mathrm{C}$, respectively. The three-year average temperatures in spring, summer, fall, and winter were $17.0,27.5,19.7$ and $6.9^{\circ} \mathrm{C}$, respectively. In Nanjing, The average monthly maximum temperatures in 2018,2019 , and 2020 were $33.0^{\circ} \mathrm{C}, 32.0^{\circ} \mathrm{C}$, and $33.0^{\circ} \mathrm{C}$; the average monthly minimum temperatures were $-2.0^{\circ} \mathrm{C}, 1.0^{\circ} \mathrm{C}$, and $1.0^{\circ} \mathrm{C}$; the annual average temperatures were $16.6^{\circ} \mathrm{C}, 16.6^{\circ} \mathrm{C}$, and $16.5^{\circ} \mathrm{C}$, and the three-year average temperatures in spring, summer, fall, and winter were $16.727 .1,18.0$, and $4.7^{\circ} \mathrm{C}$, respectively. Because of its geographical location, the average temperature in Nanjing was lower than that in Shanghai.

As shown in Figs. 2(a), 2(b), and 2(c), the average particle phase fractions for the phase distribution of total-PCDD/Fs-WHO ${ }_{2005}$-TEQ in Shanghai in 2018 were approximately $57.1 \%, 16.4 \%$, $40.9 \%$, and $84.2 \%$ in the spring, summer, autumn, and winter, respectively. Similarly, those in 2019 were $60.0 \%, 19.0 \%, 43.1 \%$, and $81.8 \%$, respectively, and those in 2020 were $56.1 \%, 17.2 \%$, $40.9 \%$, and $76.9 \%$, respectively. From 2018 to 2020, the fractions of particle-bound PCDD/Fs for the low molecular weight PCDD/F homologues were calculated. For example, in 2018, 2019, and 2020, for 2,3,7,8-TCDD, they were $24.3 \%, 23.2 \%$ and $17.9 \%$; for 2,3,7,8-TCDF, they were $14.5 \%$, $13.9 \%$ and $10.2 \%$, respectively. For the middle molecular weight PCDD/F homologues, they were as follows: For $1,2,3,7,8-\mathrm{PeCDD}$, they were $46.5 \%, 48.3 \%$, and $41.2 \%$, and for $1,2,3,7,8-\mathrm{PeCDF}$, they were $36.2 \%, 36.6 \%$ and $29.8 \%$, respectively. However, for the high molecular weight PCDD/F homologues they were as follows: For 1,2,3,4,6,7,8,9-OCDD, they were 97.3\%, 97.8\%, and 97.1\% and for $1,2,3,4,6,7,8,9-\mathrm{OCDF}$, they were $97.8 \%, 98.2 \%$ and $97.7 \%$, respectively (Fig. 3). The above results indicate that low molecular weight PCDD/F homologues mainly exist in the gas phase, while high molecular weight PCDD/F homologues are typically associated with particulates. This is due to the fact that a low molecular weight PCDD/F homologue has a higher vapor pressure.

As shown in Figs. 2(d), 2(e), and 2(f), the average particle phase fractions of total-PCDD/Fs$\mathrm{WHO}_{2005}$-TEQ in Nanjing in 2018 were approximately $62.5 \%, 20.4 \%, 53.8 \%$, and $91.6 \%$ in the spring, summer, autumn, and winter season, respectively. In the four seasons (spring, summer, autumn, and winter) of 2019 , the average particle phase fractions were $65.3 \%, 23.0 \%, 53.5 \%$, and $90.0 \%$, 
Table 2. Monthly minimum, maximum and average temperatures in Shanghai and Nanjing from 2018-2020 (Unit: $\left.{ }^{\circ} \mathrm{C}\right)$.

\begin{tabular}{|c|c|c|c|c|c|c|c|}
\hline \multicolumn{2}{|l|}{ City } & \multicolumn{3}{|c|}{ Shanghai } & \multicolumn{3}{|c|}{ Nanjing } \\
\hline Year & Month & Minimum & Maximum & Average & Minimum & Maximum & Average \\
\hline \multirow[t]{12}{*}{2018} & Jan. & 2.0 & 7.0 & 4.5 & -2.0 & 5.0 & 1.5 \\
\hline & Feb. & 2.0 & 9.0 & 5.5 & 0.0 & 8.0 & 4.0 \\
\hline & Mar. & 9.0 & 16.0 & 12.5 & 7.0 & 17.0 & 12.0 \\
\hline & Apr. & 14.0 & 22.0 & 18.0 & 13.0 & 22.0 & 17.5 \\
\hline & May & 19.0 & 26.0 & 22.5 & 18.0 & 25.0 & 21.5 \\
\hline & June & 22.0 & 29.0 & 25.5 & 21.0 & 30.0 & 25.5 \\
\hline & July & 26.0 & 33.0 & 29.5 & 26.0 & 33.0 & 29.5 \\
\hline & Aug. & 27.0 & 32.0 & 29.5 & 25.0 & 32.0 & 28.5 \\
\hline & Sep. & 23.0 & 29.0 & 26.0 & 21.0 & 28.0 & 24.5 \\
\hline & Oct. & 16.0 & 22.0 & 19.0 & 13.0 & 22.0 & 17.5 \\
\hline & Nov. & 12.0 & 18.0 & 15.0 & 9.0 & 16.0 & 12.5 \\
\hline & Dec. & 6.0 & 10.0 & 8.0 & 2.0 & 8.0 & 5.0 \\
\hline \multirow[t]{12}{*}{2019} & Jan. & 4.0 & 8.0 & 6.0 & 1.0 & 6.0 & 3.5 \\
\hline & Feb. & 5.0 & 8.0 & 6.5 & 2.0 & 6.0 & 4.0 \\
\hline & Mar. & 8.0 & 15.0 & 11.5 & 7.0 & 16.0 & 11.5 \\
\hline & Apr. & 14.0 & 20.0 & 17.0 & 13.0 & 21.0 & 17.0 \\
\hline & May & 17.0 & 25.0 & 21.0 & 16.0 & 26.0 & 21.0 \\
\hline & June & 21.0 & 27.0 & 24.0 & 21.0 & 29.0 & 25.0 \\
\hline & July & 25.0 & 30.0 & 27.5 & 24.0 & 31.0 & 27.5 \\
\hline & Aug. & 25.0 & 32.0 & 28.5 & 24.0 & 32.0 & 28.0 \\
\hline & Sep. & 22.0 & 27.0 & 24.5 & 20.0 & 28.0 & 24.0 \\
\hline & Oct. & 17.0 & 23.0 & 20.0 & 14.0 & 23.0 & 18.5 \\
\hline & Nov. & 12.0 & 17.0 & 14.5 & 8.0 & 17.0 & 12.5 \\
\hline & Dec. & 6.0 & 11.0 & 8.5 & 3.0 & 11.0 & 7.0 \\
\hline \multirow[t]{12}{*}{2020} & Jan. & 5.0 & 9.0 & 7.0 & 2.0 & 7.0 & 4.5 \\
\hline & Feb. & 7.0 & 12.0 & 9.5 & 4.0 & 12.0 & 8.0 \\
\hline & Mar. & 9.0 & 16.0 & 12.5 & 7.0 & 17.0 & 12.0 \\
\hline & Apr. & 12.0 & 20.0 & 16.0 & 10.0 & 20.0 & 15.0 \\
\hline & May & 19.0 & 26.0 & 22.5 & 17.0 & 28.0 & 22.5 \\
\hline & June & 23.0 & 28.0 & 25.5 & 21.0 & 28.0 & 24.5 \\
\hline & July & 24.0 & 30.0 & 27.0 & 23.0 & 28.0 & 25.5 \\
\hline & Aug. & 27.0 & 34.0 & 30.5 & 26.0 & 33.0 & 29.5 \\
\hline & Sep. & 21.0 & 27.0 & 24.0 & 19.0 & 27.0 & 23.0 \\
\hline & Oct. & 16.0 & 22.0 & 19.0 & 13.0 & 21.0 & 17.0 \\
\hline & Nov. & 13.0 & 17.0 & 15.0 & 9.0 & 16.0 & 12.5 \\
\hline & Dec. & 4.0 & 10.0 & 7.0 & 1.0 & 8.0 & 4.5 \\
\hline
\end{tabular}

respectively. Those during 2020 were, on average, $61.8 \%, 21.0 \%, 51.6 \%$, and $86.0 \%$, respectively From 2018-2020, the fractions of particle-bound PCDD/Fs for the low molecular weight PCDD/F homologues were as follows: For $2,3,7,8-\mathrm{TCDD}$, they were $38.0 \%, 36.2 \%$, and $31.2 \%$ on average, and for $2,3,7,8-\mathrm{TCDF}$, they were $25.0 \%, 23.6 \%$ and $19.7 \%$, on average, respectively. The middle molecular weight PCDD/F homologues were as follows: For 1,2,3,7,8-PCDD, they were $58.5 \%$, $59.1 \%$, and $54.4 \%$, on average, and for $1,2,3,7,8-P e C D F$, they were $49.0 \%, 48.8 \%$ and $43.8 \%$, on average, respectively. However, for the high molecular weight PCDD/F homologues, they were as follows: for $1,2,3,4,6,7,8,9-O C D D$, they were $98.2 \%, 98.6 \%$, and $98.2 \%$, on average, and for $1,2,3,4,6,7,8,9-$ OCDF, they were $98.7 \%, 98.8 \%$ and $98.6 \%$, on average, respectively. The average particle phase fractions of total-PCDD/Fs-WHO $2005-\mathrm{TEQ}$ in 2018 and 2019 were $57.1 \%$ and $58.0 \%$. In 2020, the average particle phase fractions was $55.1 \%$, which was lower than in previous years. Based on data from Nanjing in the last three years, the average particle phase fractions of gasparticle partitioning of total-PCDD/Fs-WHO $\mathrm{WH}_{205}$-TEQ for 2020 was significantly lower than it 

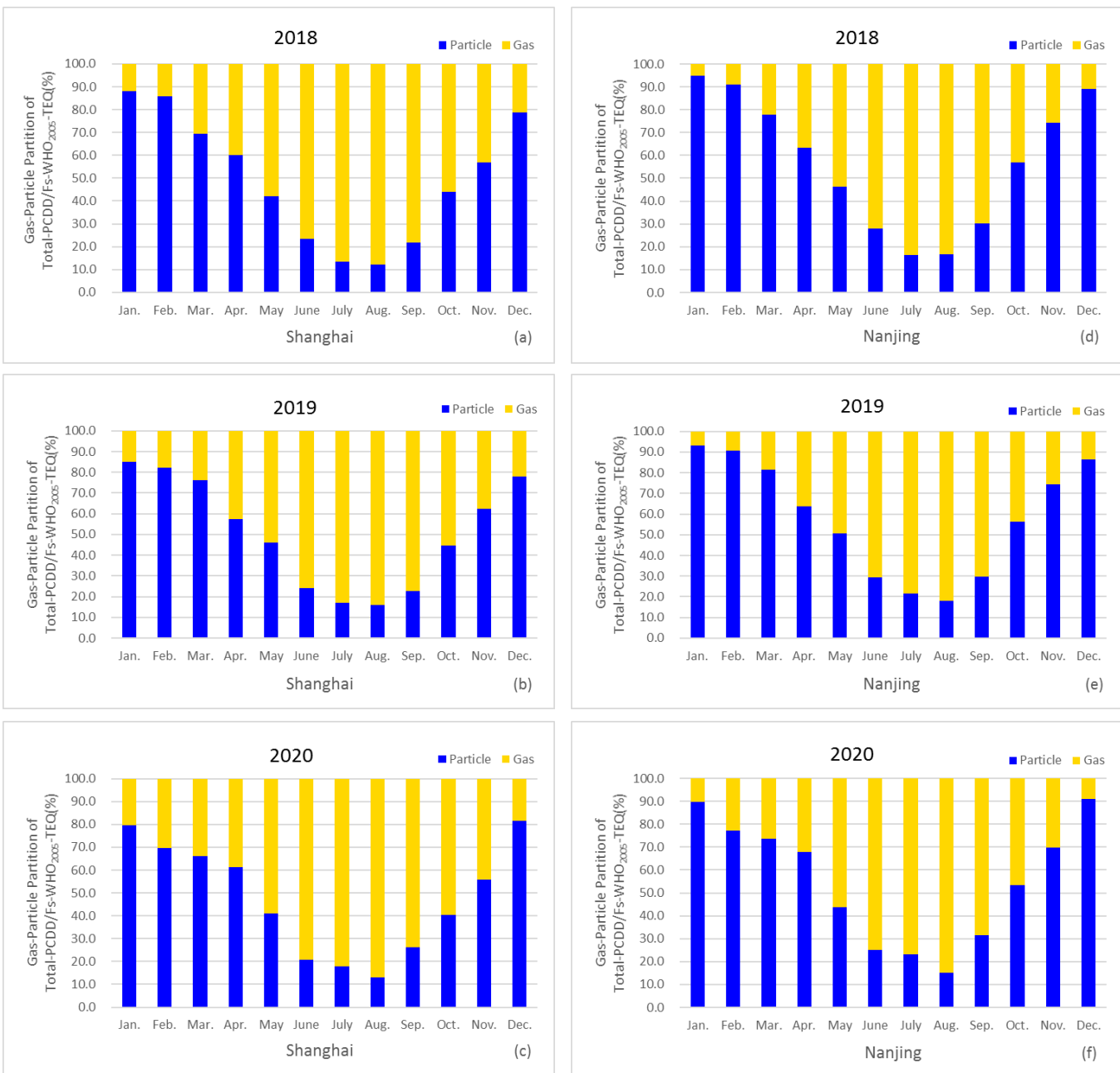

Fig. 2. Monthly gas-particle partition of total-PCDD/Fs-WHO2005-TEQ in Shanghai and Nanjing in 2018,2019 , and 2020, respectively.

was in 2018 and 2019. The results show that the particle phase fractions of total-PCDD/Fs$\mathrm{WHO}_{2005}$-TEQ were obviously higher than those in the gas phase in spring and winter, but were significantly lower than those in the gas phase in summer. However, in autumn, the difference between the gas and particle phase fractions was less. In general, lower molecular weight $\mathrm{PCDD} / \mathrm{Fs}$ congeners occur mainly in the gas phase, while the particle phase is usually combined with the higher molecular weight PCDD/Fs congeners. The distribution proportion of compounds in the particle phase in 2020 was significantly lower than that in 2018-2019. When the control measures were implemented in 2020, the particle phase fractions were significantly reduced, indicating that the number of PCDD/Fs congeners in high polymers was obviously reduced, which is conducive to environmentally friendly development.

\section{3 $\mathrm{PM}_{2.5}$ Concentration}

High concentrations of $\mathrm{PM}_{2.5}$ are harmful to human health. The $\mathrm{PM}_{2.5}$ levels in Shanghai and Nanjing in the period from 2018-2020 are shown in Fig 4.

As shown in Fig. 4(a), the PM 2.5 concentrations in Shanghai in the four seasons (spring, summer, autumn, and winter) of 2018 ranged between 38 and 41, between 15 and 32, between 24 and 40, and between 36 and $57 \mu \mathrm{g} \mathrm{m}^{-3}$, and averaged 39.3, 22.0, 29.7, and $45.7 \mu \mathrm{g} \mathrm{m}^{-3}$, respectively. In 2018 in Shanghai, the average $\mathrm{PM}_{2.5}$ concentrations $\left(42.5 \mu \mathrm{g} \mathrm{m}^{-3}\right)$ in spring and winter were $48.2 \%$ higher than in summer $\left(22.0 \mu \mathrm{g} \mathrm{m}^{-3}\right)$. In the four seasons of 2019, $\mathrm{PM}_{2.5}$ concentrations ranged from 33 to 51 , from 24 to 29 , from 21 to 31 , and from 41 to $50 \mu \mathrm{g} \mathrm{m}{ }^{-3}$, and averaged 41.3, 26.3, 26.3 , and $46.7 \mu \mathrm{g} \mathrm{m}^{-3}$, respectively. In 2019 , the average $\mathrm{PM}_{2.5}$ concentration $\left(44.0 \mu \mathrm{g} \mathrm{m}^{-3}\right)$ of 

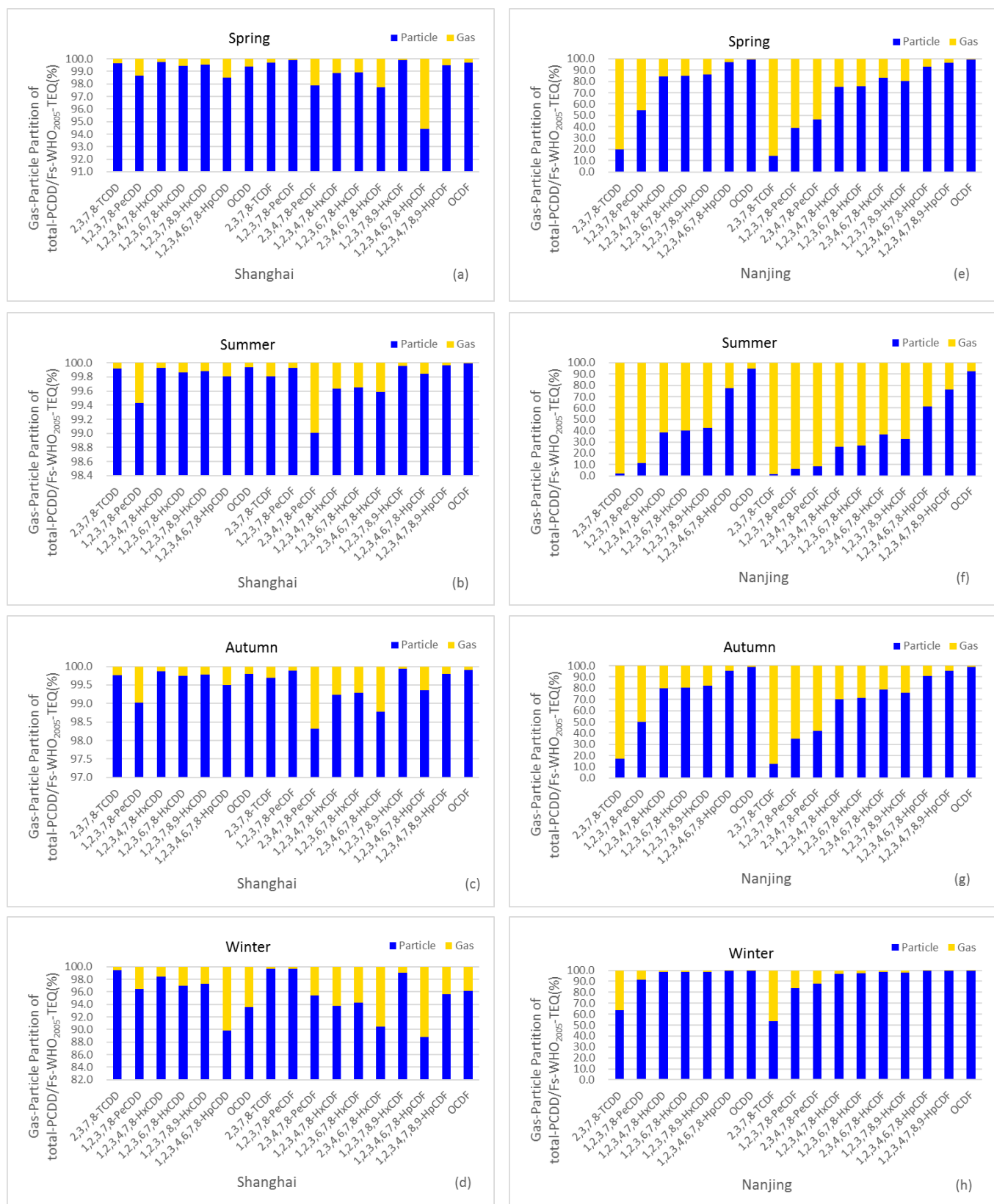

Fig. 3. Seasonal gas-particle partitioning of PCDD/Fs in Shanghai and Nanjing from 2018-2020.

those spring and winter was $40.2 \%$ higher than that in summer $\left(26.3 \mu \mathrm{g} \mathrm{m}^{-3}\right)$. While during 2020 , the concentrations ranged from $27-39,20-30,19-27$, and 33-54 $\mu \mathrm{g} \mathrm{m}^{-3}$, and averaged 33.0, 25.7, 23.7 , and $44.7 \mu \mathrm{g} \mathrm{m}^{-3}$, respectively. In 2020 , the average $\mathrm{PM}_{2.5}$ concentrations $\left(38.8 \mu \mathrm{g} \mathrm{m}^{-3}\right)$ in spring and winter were $40.2 \%$ higher than those in summer $\left(25.7 \mu \mathrm{g} \mathrm{m}^{-3}\right)$. In addition, the average $\mathrm{PM}_{2.5}$ concentrations in 2018 and 2019 were 34.2 and $35.2 \mu \mathrm{g} \mathrm{m}^{-3}$, respectively, which indicated no significant difference. In 2020, the average $\mathrm{PM}_{2.5}$ concentration was $31.8 \mu \mathrm{g} \mathrm{m}^{-3}$, which was 8.4\% lower than the average in 2018 and 2019.

As shown in Fig. 4(b), the PM 2.5 concentrations in Nanjing in the four seasons (spring, summer, autumn, and winter) of 2018 ranged between 30 and 45, between 21 and 27, between 27 and 56, and between 50 and $82 \mu \mathrm{g} \mathrm{m}^{-3}$, and averaged 36.7, 23.7, 39.0, and $62.0 \mu \mathrm{g} \mathrm{m}^{-3}$, respectively. In 2018 in Nanjing, the average $\mathrm{PM}_{2.5}$ concentrations $\left(49.3 \mu \mathrm{g} \mathrm{m}^{-3}\right)$ in spring and winter were $52.0 \%$ higher than those in summer $\left(23.7 \mu \mathrm{g} \mathrm{m}^{-3}\right)$. In the four seasons of 2019, the $\mathrm{PM}_{2.5}$ concentrations ranged from 31 to 54 , from 19 to 29 , from 24 to 37 , and from 53 to $74 \mu \mathrm{g} \mathrm{m}^{-3}$, and averaged 42.0, $24.3,32.7$, and $62.3 \mu \mathrm{g} \mathrm{m}^{-3}$, respectively. $\ln 2019$, the average $\mathrm{PM}_{2.5}$ concentrations $\left(52.2 \mu \mathrm{g} \mathrm{m}^{-3}\right)$ in 


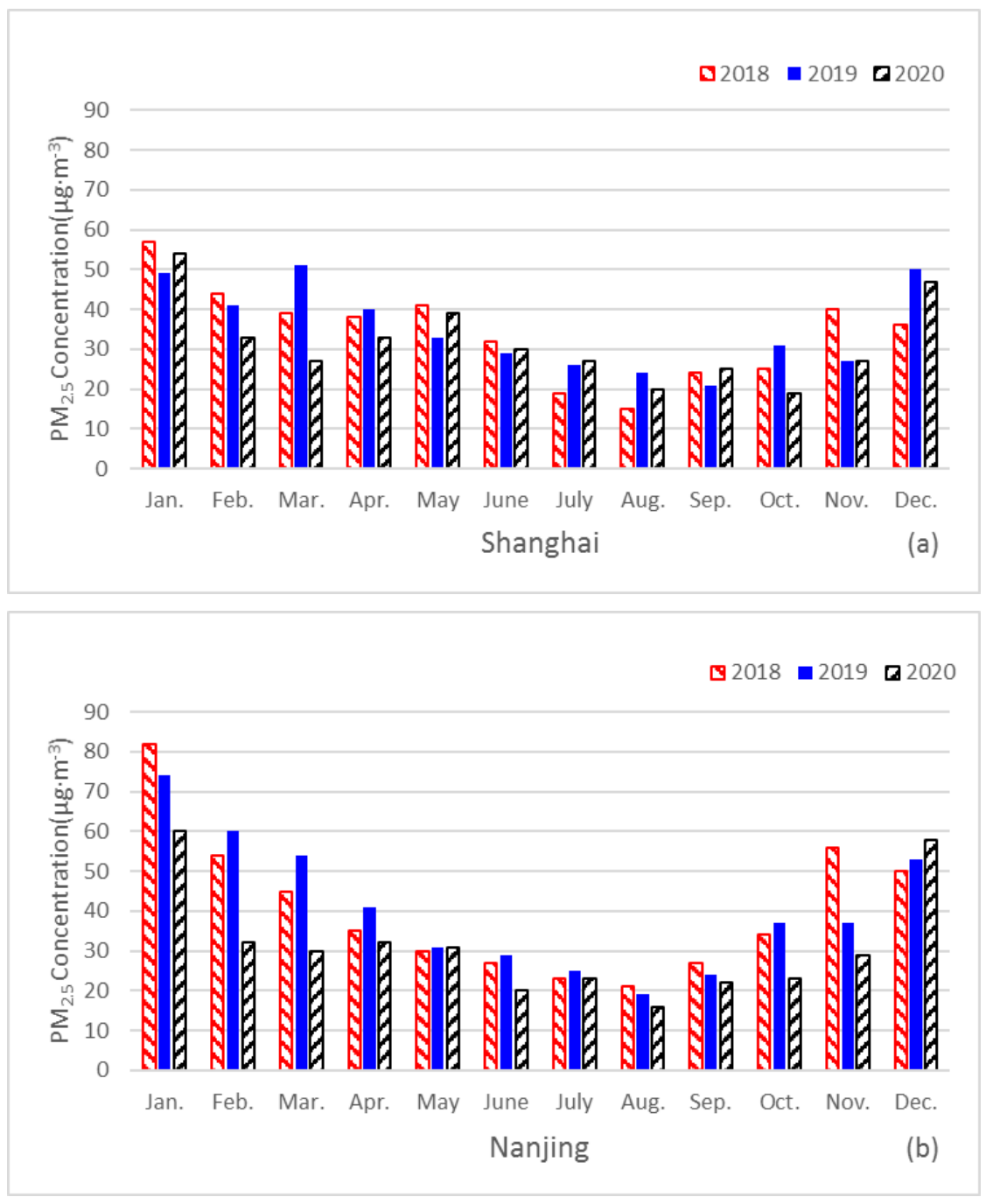

Fig. 4. Monthly $\mathrm{PM}_{2.5}$ concentration in Shanghai and Nanjing in 2018,2019 , and 2020, respectively.

spring and winter were $53.4 \%$ higher than those in summer $\left(24.3 \mu \mathrm{g} \mathrm{m}^{-3}\right)$. Those during 2020 ranged from 30-32, 16-23, 22-29, and 32-60 $\mathrm{g} \mathrm{m} \mathrm{m}^{-3}$, and averaged 31.0, 19.7, 24.7, and $50.0 \mu \mathrm{g} \mathrm{m}^{-3}$, respectively. In 2020, the average $\mathrm{PM}_{2.5}$ concentrations $\left(40.5 \mu \mathrm{g} \mathrm{m}^{-3}\right)$ in spring and winter were $51.4 \%$ higher than those in summer $\left(19.7 \mu \mathrm{g} \mathrm{m}^{-3}\right)$. In addition, the average $\mathrm{PM}_{2.5}$ concentrations in 2018 and 2019 were both $40.3 \mu \mathrm{g} \mathrm{m}^{-3}$, and the average $\mathrm{PM}_{2.5}$ concentration in 2020 was $31.3 \mu \mathrm{g} \mathrm{m}^{-3}$, which was $22.3 \%$ lower than that in the period from 2018-2019.

Due to the COVID-19 outbreak in February 2020, PM2.5 concentrations in Shanghai and Nanjing were $22.4 \%$ and $43.9 \%$ lower than those in February 2018-19, respectively. This is because in February of 2020, enterprises and factories were shut down, and the government called on people to quarantine at home. The control measures resulted in a significant reduction in vehicle exhaust emissions, and the $\mathrm{PM}_{2.5}$ concentration dropped significantly. Based on the above results, the control measures under the COVID-19 epidemic had a significant positive influence on air quality.

\section{4 $\mathrm{PM}_{2.5}$-bound Total PCDD/Fs-WHO 2005 -TEQ Content}

The content of $\mathrm{PM}_{2.5}$-bound total PCDD/Fs-WHO 2005 -TEQ in Shanghai and Nanjing during the period from 2018-2020 is shown in Fig. 5. In 2018, in Shanghai, the PM2.5-bound total PCDD/Fs$\mathrm{WHO}_{2005}-\mathrm{TEQ}$ content ranged between 0.097 and $0.595 \mathrm{ng}-\mathrm{WHO}_{2005}-\mathrm{TEQ} \mathrm{g}^{-1}$ and averages 0.337 ng- $\mathrm{WHO}_{2005}-\mathrm{TEQ} \mathrm{g}^{-1}$. In 2018 in Shanghai, the average PM2.5-bound total PCDD/Fs-WHO $2005-\mathrm{TEQ}$ content $\left(0.472 \mathrm{ng}-\mathrm{WHO}_{2005}-\mathrm{TEQ} \mathrm{g}^{-1}\right)$ in the spring and winter was $77.9 \%$ higher than that in summer (0.105 ng-WHO $\mathrm{WH}_{205}-\mathrm{TEQ} \mathrm{g}^{-1}$ ). In 2019, the content of PM2.5-bound total PCDD/Fs-WHO 2005 -TEQ 
ranged between 0.089 and $0.649 \mathrm{ng}-\mathrm{WHO}_{2005}-\mathrm{TEQ} \mathrm{g}^{-1}$ and averaged $0.346 \mathrm{ng}-\mathrm{WHO}_{2005}-\mathrm{TEQ} \mathrm{g}^{-1}$. In 2019, the average $\mathrm{PM}_{2.5}$-bound total PCDD/Fs-WHO 2005 -TEQ content $\left(0.439 \mathrm{ng}-\mathrm{WHO}_{2005}-\mathrm{TEQ} \mathrm{g}^{-1}\right.$ ) in spring and winter was $77.7 \%$ higher than that in summer $\left(0.098 \mathrm{ng}-\mathrm{WHO}_{2005}-\mathrm{TEQ} \mathrm{g}^{-1}\right)$. In 2020, the $\mathrm{PM}_{2.5}$-bound total PCDD/Fs-WHO 2005 -TEQ content ranged between 0.091 and $0.543 \mathrm{ng}-\mathrm{WHO}_{2005-}$ TEQ g ${ }^{-1}$ and averaged $0.312 \mathrm{ng}-\mathrm{WHO}_{2005}$ TEQ g$^{-1}$. In 2020, the average $\mathrm{PM}_{2.5}$-bound total PCDD/Fs$\mathrm{WHO}_{2005}$-TEQ content $\left(0.402 \mathrm{ng}-\mathrm{WHO}_{2005}\right.$ TEQ g $\left.^{-1}\right)$ in spring and winter was $77.0 \%$ higher than that in summer $\left(0.093 \mathrm{ng}-\mathrm{WHO}_{2005}-\mathrm{TEQ} \mathrm{g}^{-1}\right)$. As for seasonal variations, for Shanghai, in 2018, the $\mathrm{PM}_{2.5}$-bound total PCDD/Fs-WHO $\mathrm{W}_{2005}$-TEQ content in spring, summer, fall, and winter was 0.453 ,

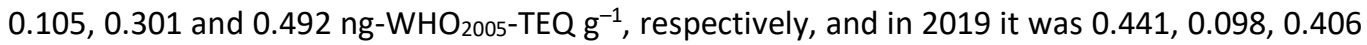
and $0.438 \mathrm{ng}-\mathrm{WHO}_{2005}$-TEQ $\mathrm{g}^{-1}$, respectively. In 2020, it was $0.451,0.093,0.352$ and $0.353 \mathrm{ng}$ $\mathrm{WHO}_{2005}$-TEQ $\mathrm{g}^{-1}$, respectively. Compared with the same period in the summer and winter of 2018-2019, the content decreased by $8.7 \%$ and $24.1 \%$, while the decrease was slower or even increased in the spring and autumn. Overall, the annual $\mathrm{PM}_{2.5}$-bound total PCDD/Fs-WHO 2005 -TEQ content in $2020\left(0.312 \mathrm{ng}-\mathrm{WHO}_{2005}\right.$-TEQ $\left.\mathrm{g}^{-1}\right)$ was lower than the average from 2018-2019 $\left(0.342\right.$ ng-WHO $\left.2005-\mathrm{TEQ} \mathrm{g}^{-1}\right)$.

As shown in Fig. 5(b), in Nanjing, the PM2.5-bound total PCDD/Fs-WHO ${ }_{2005}$-TEQ content ranged between 0.126 and $0.771 \mathrm{ng}-\mathrm{WHO}_{2005}-\mathrm{TEQ} \mathrm{g}^{-1}$ and averaged $0.479 \mathrm{ng}-\mathrm{WHO}_{2005}-\mathrm{TEQ} \mathrm{g}^{-1}$ in 2018. In 2018 in Nanjing, the average PM2.5-bound total PCDD/Fs-WHO 2005 -TEQ contents $(0.672 \mathrm{ng}$ $\left.\mathrm{WHO}_{2005}-\mathrm{TEQ} \mathrm{g}^{-1}\right)$ in spring and winter was $75.0 \%$ higher than that in summer $\left(0.160 \mathrm{ng}-\mathrm{WHO}_{2005-}\right.$ TEQ ${ }^{-1}$ ). In 2019, the content of $\mathrm{PM}_{2.5}$-bound total PCDD/Fs-WHO ${ }_{2005}$-TEQ ranged between 0.153

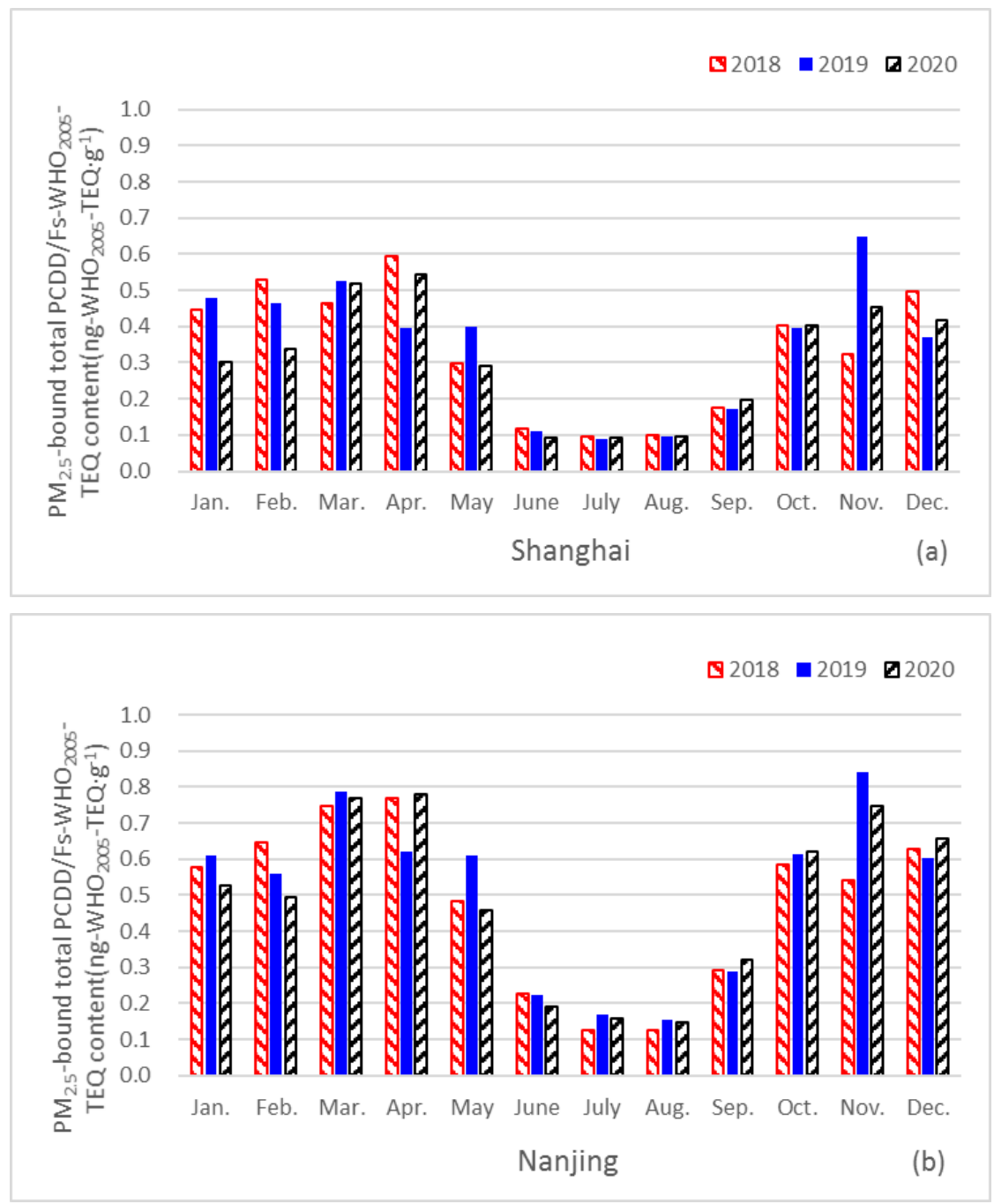

Fig. 5. Monthly $\mathrm{PM}_{2.5}$-bound total PCDD/Fs-WHO 2005 -TEQ content in Shanghai and Nanjing in the period from 2018-2020, respectively. 
and $0.841 \mathrm{ng}-\mathrm{WHO}_{2005}$-TEQ $\mathrm{g}^{-1}$ and averaged $0.506 \mathrm{ng}-\mathrm{WHO}_{2005}-\mathrm{TEQ} \mathrm{g}^{-1}$. In 2019, the average $\mathrm{PM}_{2.5}$-bound total PCDD/Fs-WHO 2005 -TEQ content $\left(0.631 \mathrm{ng}-\mathrm{WHO}_{2005}-\mathrm{TEQ} \mathrm{g}^{-1}\right)$ in spring and winter was $71.3 \%$ higher than that in summer $\left(0.181 \mathrm{ng}-\mathrm{WHO}_{2005}-\mathrm{TEQ} \mathrm{g}^{-1}\right)$. In 2020, the $\mathrm{PM}_{2.5}$-bound total PCDD/Fs-WHO $\mathrm{WH}_{205}$-TEQ content ranged between 0.148 and $0.779 \mathrm{ng}-\mathrm{WHO}_{2005}-\mathrm{TEQ}^{-1}$ and averaged 0.489 ng-WHO $\mathrm{WH}_{200}-\mathrm{TEQ} \mathrm{g} \mathrm{g}^{-1}$. In 2020, the average $\mathrm{PM}_{2.5}$-bound total PCDD/Fs-WHO $\mathrm{W}_{2005}$ TEQ content $\left(0.614 \mathrm{ng}-\mathrm{WHO}_{2005}-\mathrm{TEQ} \mathrm{g}^{-1}\right)$ in spring and winter was $73.1 \%$ higher than that in summer $\left(0.165 \mathrm{ng}-\mathrm{WHO}_{2005}-\mathrm{TEQ} \mathrm{g}^{-1}\right)$. As for the seasonal variations, for Nanjing, in 2018, the $\mathrm{PM}_{2.5}$ bound total PCDD/Fs-WHO $\mathrm{WH}_{205}$-TEQ content in spring, summer, fall, and winter was 0.666, 0.160, 0.473 and 0.617 ng-WHO $2005-T E Q g^{-1}$, respectively. In 2019 it was $0.672,0.181,0.581$ and 0.591 ng- $\mathrm{WHO}_{2005}-\mathrm{TEQ} \mathrm{g}^{-1}$, respectively, and in 2020, it was $0.669,0.165,0.563$ and $0.560 \mathrm{ng}-\mathrm{WHO}_{2005}-$ TEQ $\mathrm{g}^{-1}$, respectively. Compared with the same period in the summer and winter in the period from $2018-2019$, the content decreased by $3.0 \%$ and $7.3 \%$, but it increased in the autumn. Overall, the $\mathrm{PM}_{2.5}$-bound total PCDD/Fs-WHO 2005 -TEQ in 2020 (0.489 ng-WHO 2005 -TEQ g ${ }^{-1}$ ) were slightly lower than during 2018-2019 (0.493 ng-WHO $\left.2005-\mathrm{TEQ} \mathrm{g}^{-1}\right)$.

On the whole, the content of the $\mathrm{PM}_{2.5}$-bound total PCDD/Fs- $\mathrm{WHO}_{2005}$-TEQ was the lowest in summer and the highest in winter, which was due to the fact that high temperatures in summer caused the evaporation of a large amount of PCDD/Fs from the particle to the gas phase, so the content of PCDD/Fs particle-bound in $\mathrm{PM}_{2.5}$ was reduced.

\subsection{Dry Deposition of Total-PCDD/Fs-WHO 2005 -TEQ}

The dry deposition of total-PCDD/Fs-WHO ${ }_{2005}$-TEQ in the gas phase occurs mainly through diffusion, while in the particle phase, it occurs mainly through gravitational settling. Table 3 shows the dry deposition of total-PCDD/Fs-WHO 2005 -TEQ in atmospheric environments in some countries and cities globally. The monthly dry deposition flux of total-PCDD/Fs-WHO ${ }_{2005}-\mathrm{TEQ}$ in Shanghai and Nanjing in 2018, 2019, and 2020 are presented in Figs. 6(a) and 6(b).

As shown in Fig. 6(a), the dry deposition fluxes of total-PCDD/Fs-WHO ${ }_{2005}$-TEQ in Shanghai in the four seasons (spring, summer, autumn, and winter) of 2018 ranged between 354.4 and 513.4, between 163.2 and 219.4, between 264.3 and 310.5, and between 309.5 and 394.4 pg $\mathrm{WHO}_{2005}-$ TEQ $\mathrm{m}^{-2}$ month $^{-1}$, and averaged 421.9, 189.4, 295.1, and $358.0 \mathrm{pg} \mathrm{WHO} 2005-\mathrm{TEQ} \mathrm{m}^{-2} \mathrm{month}^{-1}$, respectively. In 2018 in Shanghai, the average dry deposition flux of total-PCDD/Fs-WHO $2005-T E Q$ (389.9 $\mathrm{pg} \mathrm{WHO}_{2005}$-TEQ $\mathrm{m}^{-2} \mathrm{month}^{-1}$ ) in spring and winter was $51.4 \%$ higher than that in summer (189.4 pg WHO 2005 -TEQ $\mathrm{m}^{-2}$ month $^{-1}$ ). In the four seasons of 2019, the dry deposition flux of totalPCDD/Fs-WHO ${ }_{2005}$-TEQ ranged from 376.1 to 477.3 , from 180.1 to 196.9 , from 218.1 to 383.2,

Table 3. Dry deposition of total-PCDD/Fs- $\mathrm{WHO}_{2005}$-TEQ in some countries and regions in the world.

\begin{tabular}{|c|c|c|c|}
\hline Country & City & Dry deposition (ng $\mathrm{m}^{-2}$ year $^{-1}$ ) & Reference \\
\hline Belguim & Flander & $1.48-12.96$ & Vanet al., 2001 \\
\hline Italy & Venice & $0-3.31$ & Guerzoni et al., 2004 \\
\hline Korea & Daeyeon & $2.1-8.2$ & Moon et al., 2005 \\
\hline USA & Houston & $0.08-0.25$ & Correa et al., 2006 \\
\hline Japan & Kanazawa & $0.03-15.48$ & Oka et al., 2006 \\
\hline Thailand & Chiangmai & $1.0-1.6$ & Trinh et al., 2018 \\
\hline China & Beijing & $2.4-84.1$ & Trinh et al., 2018 \\
\hline \multirow[t]{2}{*}{ Vietnam } & Danang & $3.1-19.1$ & Trinh et al., 2018 \\
\hline & Sonla & $1.5-7.8$ & Trinh et al., 2018 \\
\hline Iran & & $0.58-1.19$ & Momeniha et al., 2011 \\
\hline France & Marseille & $2-80.8$ & Castro-Jimenez et al., 2017 \\
\hline Tunisia & Bizerte & $2-69.2$ & Castro-Jimenez et al., 2017 \\
\hline Taiwan Area & ---------- & $0.67-7.06$ & Lee et al., 2018 \\
\hline Turkey & Istanbul & 16.07 & Gunes et al., 2019 \\
\hline Czech Republic & & $0.42-0.57$ & Degrendele et al., 2020 \\
\hline \multirow[t]{2}{*}{ China } & Shanghai & $2.0-5.7$ & This study, 2021 \\
\hline & Nanjing & $2.5-8.5$ & This study, 2021 \\
\hline
\end{tabular}




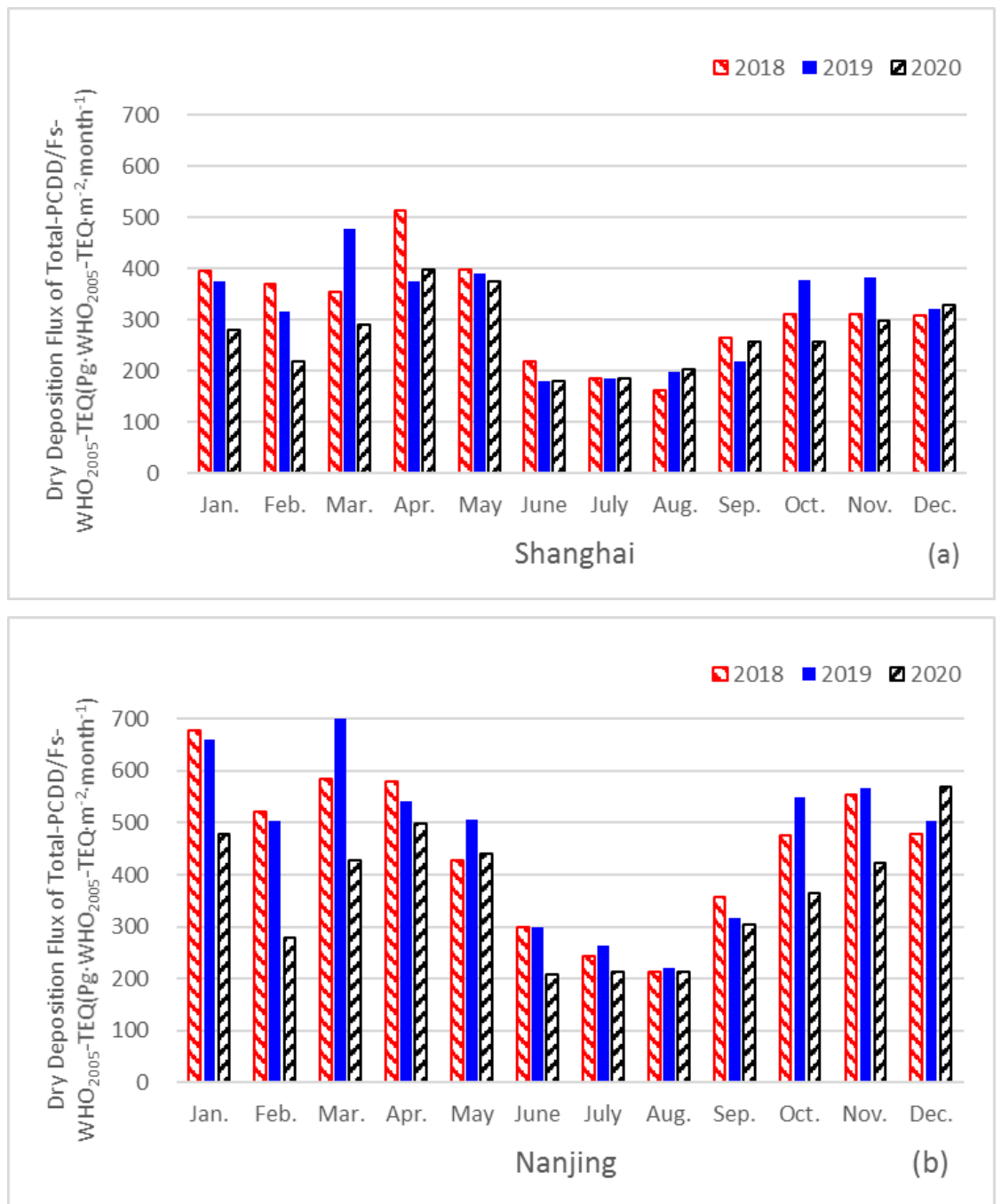

Fig. 6. Monthly dry deposition flux of total-PCDD/Fs-WHO $2005-\mathrm{TEQ}$ in Shanghai and Nanjing in 2018, 2019 and 2020, respectively.

and from 315.5 to $376.2 \mathrm{pg} \mathrm{WHO}_{2005}$-TEQ $\mathrm{m}^{-2}$ month $^{-1}$, and averaged 414.6, 187.6, 325.9, and $337.8 \mathrm{pg} \mathrm{WHO}{ }_{2005}-\mathrm{TEQ} \mathrm{m}^{-2}$ month $^{-1}$, respectively. In 2019, the average dry deposition fluxes of total-PCDD/Fs-WHO 2005 -TEQ (376.2 $\mathrm{pg} \mathrm{WHO}_{2005}$-TEQ $\left.\mathrm{m}^{-2} \mathrm{month}^{-1}\right)$ in spring and winter were $50.1 \%$ higher than those in summer (187.6 pg WHO $\left.2005-\mathrm{TEQ} \mathrm{m}^{-2} \mathrm{month}^{-1}\right)$. Those during 2020 ranged from 289.3-397.8, 180.1-202.6, 257.7-297.3, and 218.5-327.7 $\mathrm{pg} \mathrm{WHO}_{2005}-\mathrm{TEQ} \mathrm{m}^{-2} \mathrm{month}^{-1}$, and averaged 354.4, 189.4, 270.9, and $275.1 \mathrm{pg} \mathrm{WHO}_{2005}$-TEQ $\mathrm{m}^{-2} \mathrm{month}^{-1}$, respectively. In 2020, the average dry deposition flux of total-PCDD/Fs-WHO 2005 -TEQ ( $314.7 \mathrm{pg} \mathrm{WHO}_{2005}$-TEQ m ${ }^{-2} \mathrm{month}^{-1}$ ) in spring and winter was $39.8 \%$ higher than that in summer (189.4 $\mathrm{pg} \mathrm{WHO}_{2005}-\mathrm{TEQ} \mathrm{m}^{-2} \mathrm{month}^{-1}$ ). Shanghai began to implement strict epidemic prevention measures in February 2020, and the dry deposition flux of total-PCDD/Fs-WHO 2005 -TEQ in February 2020 was $32.0 \%$ lower than that in 2018-2019.The average dry deposition flux of total-PCDD/Fs-WHO 2005 -TEQ in 2018 and 2019 was 316.1 and $316.5 \mathrm{pg} \mathrm{WHO}_{2005}$-TEQ $\mathrm{m}^{-2} \mathrm{month}^{-1}$. In 2020, the average dry deposition flux was $272.5 \mathrm{pg} \mathrm{WHO} 2005$-TEQ m${ }^{-2}$ month $^{-1}$, which was $13.9 \%$ lower than in 2018-2019.

As shown in Fig. 6(b), the dry deposition flux of total-PCDD/Fs-WHO2005-TEQ in Nanjing in the four seasons (spring, summer, autumn, and winter) of 2018 ranged between 426.7 and 585.7, between 213.8 and 298.1, between 356.8 and 554.9, and between 479.3 and $679.4 \mathrm{pg}^{-2} \mathrm{WHO}_{2005}{ }^{-}$ TEQ $\mathrm{m}^{-2} \mathrm{month}^{-1}$, and averaged 530.3, 251.3, 462.4, and $560.1 \mathrm{pg} \mathrm{WHO} 2005$-TEQ $\mathrm{m}^{-2} \mathrm{month}^{-1}$, respectively. In 2018 in Nanjing, the average dry deposition flux of total-PCDD/Fs-WHO 2005 -TEQ (545.2 $\mathrm{pg} \mathrm{WHO}_{2005}$-TEQ $\mathrm{m}^{-2} \mathrm{month}^{-1}$ ) in spring and winter was $53.9 \%$ higher than that in summer (251.3 $\mathrm{pg} \mathrm{WHO}_{2005}$-TEQ $\mathrm{m}^{-2}$ month $^{-1}$ ). In the four seasons of 2019, the dry deposition flux of total- 
PCDD/Fs-WHO ${ }_{2005}$-TEQ ranged from 506.2 to 708.6 , from 219.4 to 298.1 , from 317.1 to 568.1 , and from 503.5 to $661.2 \mathrm{pg} \mathrm{WHO}_{2005}$-TEQ m $\mathrm{m}^{-2}$ month $^{-1}$, and averaged 585.7, 260.7, 477.8, and $556.1 \mathrm{pg} \mathrm{WHO} 2005-\mathrm{TEQ} \mathrm{m}^{-2}$ month $^{-1}$, respectively. In 2019, the average dry deposition flux of total-PCDD/Fs-WHO 2005 -TEQ (570.9 pg $\mathrm{WHO}_{2005}$-TEQ $\mathrm{m}^{-2} \mathrm{month}^{-1}$ ) in spring and winter was $54.3 \%$ higher than that in summer (260.7 $\mathrm{pg} \mathrm{WHO}_{2005}$-TEQ $\mathrm{m}^{-2} \mathrm{month}^{-1}$ ). In 2020, it ranged from 426.7-499.0, 208.2-213.8, 303.9-422.8, and 279.1-570.9 pg WHO $2005-\mathrm{TEQ} \mathrm{m} \mathrm{month}^{-1}$, and averaged 455.6, 211.9, 363.4, and $442.9 \mathrm{pg} \mathrm{WHO}_{2005}$-TEQ $\mathrm{m}^{-2}$ month $^{-1}$, respectively. In 2020, the average dry deposition flux of total-PCDD/Fs-WHO ${ }_{2005}$-TEQ (449.2 $\mathrm{pg} \mathrm{WHO}_{2005}$-TEQ m $\mathrm{month}^{-1}$ ) in spring and winter was $52.8 \%$ higher than that in summer (211.9 $\mathrm{pg} \mathrm{WHO}_{2005}$-TEQ $\mathrm{m}^{-2} \mathrm{month}^{-1}$ ). Due to the COVID-19 outbreak, the dry deposition flux of total-PCDD/Fs-WHO 2005 -TEQ in February 2020 in Nanjing was 17.8\% lower than the average in 2018-2019. The average dry deposition flux of total-PCDD/Fs-WHO 2005 -TEQ in 2018 and 2019 was 451.0 and 470.1 pg WHO $2005-\mathrm{TEQ} \mathrm{m}^{-2} \mathrm{month}^{-1}$. In 2020, the average dry deposition flux was 368.4 pg WHO $2005-\mathrm{TEQ} \mathrm{m}^{-2}$ month $^{-1}$, which was $20.0 \%$ lower than that in 2018-2019.

The dry deposition flux of total-PCDD/Fs-WHO ${ }_{2005}$-TEQ contributed by gas and particle phase PCDD/Fs, respectively, in Shanghai and Nanjing is shown in Table 4. It can be seen that the dry deposition flux was mainly contributed by the particle phase (averaged $98.88 \%$ ), and the contribution of the particle phase fraction on the PCDD/F dry deposition flux decreased with increases in the temperature. This could have been due to the fact that more of the particle-bound PCDD/Fs were shifted to the gas phase during the high temperature season. The proportion of particle phase deposition flux in 2020 (average $98.84 \%$ ) of $4.65 \%$ and $7.26 \%$ was smaller than that in $2018-2019$ (average $98.89 \%$ and $98.92 \%$, respectively). Effective control measures can thus significantly reduce particulate pollutants in the atmosphere and improve the air quality.

On average, more than $98.88 \%$ of the total PCDD/Fs-WHO ${ }_{2005}$-TEQ dry deposition flux was primarily contributed by the particle phase. This was due to the fact that dry deposition of particle phase PCDD/Fs are mainly caused by gravitational settling due to higher dry deposition velocities, while that of gas phase PCDD/Fs are deposited mostly by diffusion, which is due to a lower dry deposition velocity.

It can be seen that seasonal variation of total-PCDD/Fs-WHO ${ }_{2005}-\mathrm{TEQ}$ dry deposition flux was the highest in winter, followed by spring and summer, in that order. In addition, the annual variations in concentration and the average dry deposition flux of total-PCDD/Fs-WHO $2005-\mathrm{TEQ}$ in 2020 for both cities ( 320.4 pg WHO 2005 -TEQ m ${ }^{-2}$ month $^{-1}$ ) were lower than those in 2018 (383.6 pg $\mathrm{WHO}_{2005}$ - TEQ $\mathrm{m}^{-2}$ month $^{-1}$ ) and 2019 (393.3 pg WHO $2005-\mathrm{TEQ} \mathrm{m}^{-2}$ month $^{-1}$ ). It can be seen that the control measures under the epidemic had a significant positive impact on air quality.

\section{CONCLUSIONS}

The results of this study can be summarized as follows:

1. The total PCDD/Fs-WHO $2005-\mathrm{TEQ}$ concentration in Shanghai in 2018-2019 (0.0291 pg-WHO $\mathrm{W}_{2005}-$ TEQ $\left.\mathrm{m}^{-3}\right)$ was $13.9 \%$ in magnitude higher than that in $2020\left(0.0250 \mathrm{pg}-\mathrm{WHO}_{2005}-\mathrm{TEQ} \mathrm{m}^{-3}\right)$, and

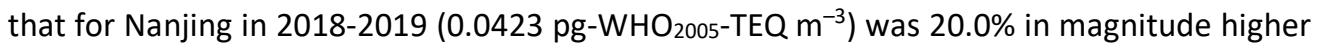
than that in $2020\left(0.0338 \mathrm{pg}-\mathrm{WHO}_{2005}-\mathrm{TEQ} \mathrm{m}^{-3}\right)$.

2. In Shanghai, the average total-PCDD/Fs- $\mathrm{WHO}_{2005}$-TEQ concentration $\left(0.0331 \mathrm{pg}-\mathrm{WHO}_{2005}-\right.$ TEQ $\left.\mathrm{m}^{-3}\right)$ in spring and winter were $47.6 \%$ of magnitude higher than those in summer $(0.0173$ pg- $\left.\mathrm{WHO}_{2005}-\mathrm{TEQ} \mathrm{m}^{-3}\right)$. Those in Nanjing in spring and winter $\left(0.479 \mathrm{pg}-\mathrm{WHO}_{2005}-\mathrm{TEQ} \mathrm{m}^{-3}\right)$ were $53.8 \%$ in magnitude higher than in summer $\left(0.222 \mathrm{pg}-\mathrm{WHO}_{2005}-\mathrm{TEQ} \mathrm{m}^{-3}\right)$, indicating that the lowest value usually occurs in summer.

3. In Shanghai, the average for the particle phase fractions of total-PCDD/Fs-WHO $2005-T E Q$ in 2018-2019 was 50.3\%, while the average in 2020 was $47.8 \%$. In Nanjing, the average particle phase fractions of total-PCDD/Fs-WHO 2005 -TEQ in 2018-2019 was $57.5 \%$, and in 2020 , the average for the particle phase fractions was $53.2 \%$.

4. In Shanghai, the $\mathrm{PM}_{2.5}$ concentration dropped from $34.7 \mu \mathrm{g} \mathrm{m}^{-3}$ in the period 2018-2019 to $31.8 \mu \mathrm{g} \mathrm{m}^{-3}$ in 2020, while in Nanjing, it dropped from $40.3 \mu \mathrm{g} \mathrm{m}^{-3}$ to $31.3 \mu \mathrm{g} \mathrm{m}^{-3}$. In 2020 , the $\mathrm{PM}_{2.5}$ concentrations in Shanghai and Nanjing were $13.9 \%$ and $20.0 \%$ lower than the average in 2018-19, respectively. Shanghai and Nanjing had better air quality in 2020 than in 
Table 4. Monthly gas-bound and particle-bound ratio of the dry deposition flux of total-PCDD/Fs-WHO ${ }_{2005}-\mathrm{TEQ}$ in Shanghai and Nanjing in 2018, 2019, and 2020 (Unit: \%).

\begin{tabular}{|c|c|c|c|c|c|}
\hline \multicolumn{2}{|l|}{ City } & \multicolumn{2}{|c|}{ Shanghai } & \multicolumn{2}{|c|}{ Nanjing } \\
\hline Year & Month & Gas-bound Ratio & Particle-bound Ratio & Gas-bound Ratio & Particle-bound Ratio \\
\hline \multirow[t]{12}{*}{2018} & Jan. & 0.28 & 99.72 & 0.12 & 99.88 \\
\hline & Feb. & 0.34 & 99.66 & 0.21 & 99.79 \\
\hline & Mar. & 0.73 & 99.27 & 0.53 & 99.47 \\
\hline & Apr. & 0.95 & 99.05 & 0.87 & 99.13 \\
\hline & May & 1.38 & 98.62 & 1.28 & 98.72 \\
\hline & June & 1.82 & 98.18 & 1.71 & 98.29 \\
\hline & July & 2.06 & 97.94 & 1.99 & 98.01 \\
\hline & Aug. & 2.09 & 97.91 & 1.98 & 98.02 \\
\hline & Sep. & 1.86 & 98.14 & 1.66 & 98.34 \\
\hline & Oct. & 1.33 & 98.67 & 1.03 & 98.97 \\
\hline & Nov. & 1.03 & 98.97 & 0.61 & 99.39 \\
\hline & Dec. & 0.51 & 99.49 & 0.26 & 99.74 \\
\hline \multirow[t]{12}{*}{2019} & Jan. & 0.35 & 99.65 & 0.17 & 99.83 \\
\hline & Feb. & 0.42 & 99.58 & 0.22 & 99.78 \\
\hline & Mar. & 0.56 & 99.44 & 0.44 & 99.56 \\
\hline & Apr. & 1.01 & 98.99 & 0.86 & 99.14 \\
\hline & May & 1.28 & 98.72 & 1.17 & 98.83 \\
\hline & June & 1.81 & 98.19 & 1.68 & 98.32 \\
\hline & July & 1.98 & 98.02 & 1.87 & 98.13 \\
\hline & Aug. & 2.00 & 98.00 & 1.95 & 98.05 \\
\hline & Sep. & 1.84 & 98.16 & 1.68 & 98.32 \\
\hline & Oct. & 1.32 & 98.68 & 1.04 & 98.96 \\
\hline & Nov. & 0.90 & 99.10 & 0.61 & 99.39 \\
\hline & Dec. & 0.52 & 99.48 & 0.33 & 99.67 \\
\hline \multirow[t]{12}{*}{2020} & Jan. & 0.49 & 99.51 & 0.25 & 99.75 \\
\hline & Feb. & 0.72 & 99.28 & 0.54 & 99.46 \\
\hline & Mar. & 0.81 & 99.19 & 0.63 & 99.37 \\
\hline & Apr. & 0.92 & 99.08 & 0.76 & 99.24 \\
\hline & May & 1.40 & 98.60 & 1.34 & 98.66 \\
\hline & June & 1.89 & 98.11 & 1.79 & 98.21 \\
\hline & July & 1.95 & 98.05 & 2.38 & 97.62 \\
\hline & Aug. & 2.07 & 97.93 & 2.02 & 97.98 \\
\hline & Sep. & 1.76 & 98.24 & 1.63 & 98.37 \\
\hline & Oct. & 1.42 & 98.58 & 1.11 & 98.89 \\
\hline & Nov. & 1.05 & 98.95 & 0.72 & 99.28 \\
\hline & Dec. & 0.44 & 99.56 & 0.21 & 99.79 \\
\hline
\end{tabular}

2018-19, especially in February. This was due to the positive effects of COVID-19 restrictions on improvement in air quality.

5. The average $\mathrm{PM}_{2.5}$ concentrations $\left(41.8 \mu \mathrm{g} \mathrm{m}^{-3}\right)$ in spring and winter were $41.0 \%$ higher than those in summer $\left(24.7 \mu \mathrm{g} \mathrm{m}^{-3}\right)$ in Shanghai, and for Nanjing in spring and winter $\left(47.3 \mu \mathrm{g} \mathrm{m}^{-3}\right)$, they were $52.3 \%$ higher than that in summer $\left(22.6 \mu \mathrm{g} \mathrm{m}^{-3}\right)$.

6. The annual $\mathrm{PM}_{2.5}$-bound total PCDD/Fs-WHO ${ }_{2005}$-TEQ content in Shanghai in $2020(0.312 \mathrm{ng}$ $\left.\mathrm{WHO}_{2005}-\mathrm{TEQ} \mathrm{g}^{-1}\right)$ was $8.6 \%$ lower than the average in 2018-2019 $\left(0.342 \mathrm{ng}-\mathrm{WHO}_{2005}-\mathrm{TEQ} \mathrm{g}^{-1}\right)$. In Nanjing in 2020 (0.489 ng-WHO $2005-\mathrm{TEQ} \mathrm{g}^{-1}$ ), it was slightly lower than that in 2018-2019 (0.493 ng-WHO $\mathrm{WHOS}-\mathrm{TEQ} \mathrm{g}^{-1}$ ).

7. In Shanghai, the average $\mathrm{PM}_{2.5}$-bound total $\mathrm{PCDD} / \mathrm{Fs}-\mathrm{WHO}_{2005}-\mathrm{TEQ}$ contents $\left(0.438 \mathrm{ng}-\mathrm{WHO}_{2005}-\right.$ $\left.\mathrm{TEQ} \mathrm{g}^{-1}\right)$ in spring and winter was $77.5 \%$ higher than that in summer $\left(0.098 \mathrm{ng}-\mathrm{WHO}_{2005}-\mathrm{TEQ} \mathrm{g}^{-1}\right)$, and that for Nanjing in spring and winter $\left(0.629 \mathrm{ng}-\mathrm{WHO}_{2005}-\mathrm{TEQ} \mathrm{g}^{-1}\right)$ was $73.2 \%$ higher than that in summer $\left(0.169 \mathrm{ng}-\mathrm{WHO}_{2005}-\mathrm{TEQ} \mathrm{g}^{-1}\right)$. 
8. The average dry deposition flux of total-PCDD/Fs-WHO $2005-T E Q$ in Shanghai in 2018-2019 (316.3 pg $\mathrm{WHO}_{2005}$-TEQ $\mathrm{m}^{-2}$ month $^{-1}$ ) was higher than that in 2020 (272.5 pg WHO 2005 -TEQ $\mathrm{m}^{-2}$ month $^{-1}$ ), and that in Nanjing in 2018-2019 (460.5 $\mathrm{WHO}_{2005}-\mathrm{TEQ} \mathrm{m}^{-2} \mathrm{month}^{-1}$ ) was higher than that in 2020 (368.4 pg WHO $2005-\mathrm{TEQ} \mathrm{m} \mathrm{m}^{-2}$ month $^{-1}$ ).

9. In Shanghai, the average dry deposition flux of total-PCDD/Fs-WHO $\mathrm{WHO}_{20}-\mathrm{TEQ}$ (360.3 pg $\mathrm{WHO}_{2005}$ TEQ $\mathrm{m}^{-2}$ month $^{-1}$ ) in spring and winter was $47.6 \%$ higher than that in summer (188.8 pg $\mathrm{WHO}_{2005}$-TEQ $\mathrm{m}^{-2}$ month $\left.^{-1}\right)$, and that in Nanjing in spring and winter (521.8 pg WHO $2005-\mathrm{TEQ}$ $\mathrm{m}^{-2}$ month $^{-1}$ ) was $53.8 \%$ higher than that in summer (241.3 pg WHO $2005-\mathrm{TEQ} \mathrm{m}^{-2} \mathrm{month}^{-1}$ ).

\section{REFERENCES}

Abad, E., Martínez, K., Gustems, L., Gomez, R., Guinart, X., Hernández, I., Rivera, J. (2007). Ten years measuring PCDDs/PCDFs in ambient air in Catalonia (Spain). Chemosphere 67, 17091714. https://doi.org/10.1016/j.chemosphere.2006.05.083

Alcock, R.E., Jones, K.C. (1996). Dioxins in the environment: A review of trend data. Environ. Sci. Technol. 30, 3133-3143. https://doi.org/10.1021/es960306z

Broman, D., Naef, C., Zebuehr, Y. (1991). Long-term high and low-volume air sampling of polychlorinated dibenzo-p-dioxins and dibenzofurans and polycyclic aromatic hydrocarbons along a transect from urban to remote areas on the Swedish Baltic Coast. Environ. Sci. Technol. 25, 1841-1850. https://doi.org/10.1021/es00023a001

Castro-Jimenez, J., Barhoumi, B., Paluselli, A., Tedetti, M., Jiménez, B., Muñoz-Arnanz, J., Wortham, J., Driss, M.R., Sempéré, R. (2017). Occurrence, loading, and exposure of atmospheric particlebound POPs at the African and European edges of the western Mediterranean Sea. Environ. Sci. Technol. 51, 13180-13189. https://doi.org/10.1021/acs.est.7b04614

Chao, M.R., Hu, C.W., Chen, Y.L., Chang-Chien, G.P., Lee, W.J., Chang, L.W., Lee, W.S., Wu, K.Y. (2004). Approaching gas-particle partitioning equilibrium of atmospheric PCDD/Fs with increasing distance from an incinerator: measurements and observations on modeling. Atmos. Environ. 38, 1501-1510. https://doi.org/10.1016/j.atmosenv.2003.11.034

Chow, J.C., Yang, X., Wang, X., Kohl, S.D., Hurbain, P.R., Chen, L.A., Watson, J.G. (2015). Characterization of ambient $\mathrm{PM}_{10}$ bioaerosols in a California agricultural town. Aerosol Air Qual. Res. 15, 1433-1447. https://doi.org/10.4209/aaqr.2014.12.0313

Coleman, P.J., Lee, R.G., Alcock, R.E., Jones, K.C. (1997). Observations on PAH, PCB, and PCDD/F trends in UK Urban air, 1991-1995. Environ. Sci. Technol. 31, 2120-2124. https://doi.org/10.10 21/es960953q

Correa, O., Raun, L., Rifai, H., Suarez, M., Holsen, T., Koenig, L. (2006). Depositional flux of polychlorinated dibenzo-p-dioxins and polychlorinated dibenzofurans in an urban setting. Chemosphere 64, 1550-1561. https://doi.org/10.1016/j.chemosphere.2005.11.020

Correa, O., Rifai, H., Raun, L., Suarez, M., Koenig, L. (2004). Concentrations and vapor-particle partitioning of polychlorinated dibenzo-p-dioxins and dibenzofurans in ambient air of Houston, TX. Atmos. Environ. 38, 6687-6699. https://doi.org/10.1016/j.atmosenv.2004.09.005

Coutinho, M., Ferreira, J., Gomes, P., Mata, P., Borrego, C. (2001). Atmospheric baseline levels of PCDD and PCDF in the region of Oporto. Chemosphere 43, 497-500. https://doi.org/10.1016/S 0045-6535(00)00400-8

de Assunção, J.V., Pesquero, C.R., Bruns, R.E., Carvalho, L.R. (2005). Dioxins and furans in the atmosphere of São Paulo City, Brazil. Chemosphere 58, 1391-1398. https://doi.org/10.1016/j. chemosphere.2004.10.003

Degrendele, C., Fiedler, H., Kočan, A., Kukučka, P., Přibylová, P., Prokeš, R., Klánová, J., Lammel, G. (2020). Multiyear levels of PCDD/Fs, dl-PCBs and PAHs in background air in central Europe and implications for deposition. Chemosphere 240, 124852. https://doi.org/10.1016/j.chemosphe re.2019.124852

Donnelly, J.R., Munslow, W.D., Mitchum, R.K., Sovocool, G.W. (1987). Correlation of structure with retention index for chlorinated dibenzo-p-dioxins. J. Chromatogr. A. 392, 51-63. https://doi.org/10.1016/S0021-9673(01)94253-0

Ghosh, S., Gupta, T., Rastogi, N., Gaur, A., Misra, A., Tripathi, S.N., Paul, D.P., Tare, V., Prakash, O., Bhattu, D., Dwivedi, A.K., Kaul, D.S., Dalai, R., Mishra, S.K. (2014). Chemical characterization of 
summertime dust events at Kanpur: Insight into the sources and level of mixing with anthropogenic emissions. Aerosol Air Qual. Res. 14, 879-891. https://doi.org/10.4209/aaqr.20 13.07.0240

Guerzoni, S., Rossini, P., Molinaroli, E., Rampazzo, G., Raccanelli, S. (2004). Measurement of atmospheric deposition of polychlorinated dibenzo-p-dioxins and dibenzofurans in the Lagoon of Venice, Italy. Chemosphere 54, 1309-1317. https://doi.org/10.1016/S0045-6535(03)00249-2

Gunes, G., Saral, A. (2019). Evaluation of atmospheric concentrations of dl-PCBs comparing to PCDD/F compounds in Istanbul, Turkey. Global Nest J. 21, 113-123. https://doi.org/10.30955/g nj.002921

Hsieh, Y.K., Chen, W.S., Zhu, J., Wu, Y.J., Huang, Q. (2018). Health risk assessment and correlation analysis on PCDD/Fs in the fly ash from a municipal solid waste incineration plant. Aerosol Air Qual. Res. 18, 734-748. https://doi.org/10.4209/aaqr.2017.12.0587

Huang, C.J., Chen, K.S., Lai, Y.C., Wang, L.C., Chang-Chien, G.P. (2011). Characterization of atmospheric dry deposition of polychlorinated dibenzo-p-dioxins/dibenzofuran in a rural area of Taiwan. Aerosol Air Qual. Res. 11,448-459. https://doi.org/10.4209/aaqr.2011.03.0033

Hung, H., Blanchard, P., Poole, G., Thibert, B., Chiu, C.H. (2002). Measurement of particle-bound polychlorinated dibenzo-p-dioxins and dibenzofurans (PCDD/Fs) in Arctic air at Alert, Nunavut, Canada. Atmos. Environ. 36, 1041-1050. https://doi.org/10.1016/S1352-2310(01)00498-8

Koester, C.J., Hites, R.A. (1992). Photodegradation of polychlorinated dioxins and dibenzofurans adsorbed to fly ash. Environ. Sci. Technol. 26, 502-507. https://doi.org/10.1021/es00027a008

Kong, S., Ji, Y., Lu, B., Zhao, X., Han, B., Bai, Z. (2014). Similarities and differences in $\mathrm{PM}_{2.5}, \mathrm{PM}_{10}$ and TSP chemical profiles of fugitive dust sources in a coastal oilfield city in China. Aerosol Air Qual. Res. 14, 2017-2028. https://doi.org/10.4209/aaqr.2013.06.0226

Lee, K. L., Lee, W. J., Mwangi, J. K., Wang, L. C., Gao, X., Chang-Chien, G. P. (2016). Atmospheric $\mathrm{PM}_{2.5}$ and depositions of polychlorinated dibenzo-p-dioxins and dibenzofurans in Kaohsiung area, southern Taiwan. Aerosol Air Qual. Res. 16, 1775-1791. https://doi.org/10.4209/aaqr.20 16.04.0168

Lee, Y. Y., Hou, W. C., Zhu, J., Wang, W. (2018). Atmospheric (dry+ wet) deposition of PCDD/Fs in Taiwan. Aerosol Air Qual. Res. 18, 2788-2800. https://doi.org/10.4209/aaqr.2018.10.0363

Li, W., Lin, X., Yu, M., Mubeen, I., Buekens, A., Li, X. (2016). Experimental study on PCDD/Fs adsorption onto nano-graphite. Aerosol Air Qual. Res. 16, 3281-3289. https://doi.org/10.4209/ aaqr.2016.08.0353

Lohmann, R., Gioia, R., Eisenreich, S.J., Jones, K.C. (2007). Assessing the importance of ab- and adsorption to the gas-particle partitioning of PCDD/Fs. Atmos. Environ. 41, 7767-7777. https://doi.org/10.1016/j.atmosenv.2007.06.010

Mandalakis, M., Tsapakis, M., Tsoga, A., Stephanou, E.G. (2002). Gas-particle concentrations and distribution of aliphatic hydrocarbons, PAHs, PCBs and PCDD/Fs in the atmosphere of Athens (Greece). Atmos. Environ. 36, 4023-4035. https://doi.org/10.1016/S1352-2310(02)00362-X

Mehta, S., Shin, H., Burnett, R., North, T., Cohen, A. J. (2013). Ambient particulate air pollution and acute lower respiratory infections: A systematic review and implications for estimating the global burden of disease. Air Qual. Atmos. Health 6, 69-83. https://doi.org/10.1007/s11869-011-0146-3

Menon, S., Hansen, J., Nazarenko, L., Luo, Y. (2002). Climate effects of black carbon aerosols in China and India. Science 297, 2250-2253. https://doi.org/10.1126/science.1075159

Momeniha, F., Nabizadeh, R., Hassanvand, M.S., Mahvi, A.H., Naddafi, K., Mesdaghinia, A., Nasseri, S. (2011). Emissions of polychlorinated dibenzo-p-dioxins and dibenzofurans (PCDD/PCDFs) in Iran. Bull. Environ. Contam. Toxicol. 87, 708-712. https://doi.org/10.1007/s00128-011-0392-y

Moon, H.B., Lee, S.J., Choi, H.G., Ok, G. (2005). Atmospheric deposition of polychlorinated dibenzo-p-dioxins (PCDDs) and dibenzofurans (PCDFs) in urban and suburban areas of Korea. Chemosphere 58, 1525-1534. https://doi.org/10.1016/j.chemosphere.2004.11.014

Oka, H., Kakimoto, H., Miyata, Y., Yonezawa, Y., Niikawa, A., Kyudoh, H., Kizu, R., Hayakawa, K. (2006). Atmospheric deposition of polychlorinated dibenzo-p-dioxins (PCDDs) and polychlorinated dibenzofurans (PCDFs) in Kanazawa, Japan. J. Health Sci. 52, 300-307. https://doi.org/10.1248/ jhs.52.300

Pankow, J.F. (1987). Review and comparative analysis of the theories on partitioning between the gas and aerosol particulate phases in the atmosphere. Atmos. Environ. 21, 2275-2283. https://doi.org/10.1016/0004-6981(87)90363-5 
Pankow, J.F., Bidleman, T.F. (1992). Interdependence of the slopes and intercepts from log-log correlations of measured gas-particle paritioning and vapor pressure-l. Theory and analysis of available data. Atmos. Environ. 26, 1071-1080. https://doi.org/10.1016/0960-1686(92)90039-N

Park, J.S., Kim, J.G. (2002). Regional measurements of PCDD/PCDF concentrations in Korean atmosphere and comparison with gas-particle partitioning models. Chemosphere 49, 755-764. https://doi.org/10.1016/S0045-6535(02)00375-2

Qiu, J., Tang, M., Peng, Y., Lu, S., Li, X., Yan, J. (2020). Characteristics of PCDD/Fs in flue gas from MSWIs and HWIs: Emission levels, profiles and environmental influence. Aerosol Air Qual. Res. 20, 2085-2097. https://doi.org/10.4209/aaqr.2019.11.0610

Sheu, H.L., Lee, W.J., Su, C.C., Chao, H.R., Fan, Y.C. (1996). Dry deposition of polycyclic aromatic hydrocarbons in ambient air. J. Environ. Eng. 122, 1101-1109. https://doi.org/10.1061/(ASCE)0 733-9372(1996)122:12(1101)

Shih, M., Lee, W.S., Chang-Chien, G.P., Wang, L.C., Hung, C.Y., Lin, K.C. (2006). Dry deposition of polychlorinated dibenzo-p-dioxins and dibenzofurans (PCDD/Fs) in ambient air. Chemosphere 62, 411-416. https://doi.org/10.1016/j.chemosphere.2005.04.064

Sin, D.W.M., Choi, J.Y.Y., Louie, P.K.K. (2002). A study of polychlorinated dibenzo-p-dioxins and dibenzofurans in the atmosphere of Hong Kong. Chemosphere 47, 647-653. https://doi.org/10. 1016/S0045-6535(01)00316-2

Suryani R., C., Lee, W.J., Mutiara M.P., E., Mwangi, J.K., Wang, L.C., Lin, N.H., Chang-Chien, G.P. (2015). Atmospheric deposition of polychlorinated dibenzo-p-dioxins and dibenzofurans at coastal and high mountain areas in Taiwan. Aerosol Air Qual. Res. 15, 1390-1411. https://doi.org/10.4209/aaqr.2015.04.0246

Trinh, M.M., Chang, M.B. (2018). Review on occurrence and behavior of PCDD/Fs and dl-PCBs in atmosphere of East Asia. Atmos. Environ. 180, 23-36. https://doi.org/10.1016/j.atmosenv.201 8.02.037

Turrio-Baldassarri, L., Carere, A., Di Domenico, A., Fuselli, S., lacovella, N., Rodriguez, F. (1994). PCDD, PCDF, and PCB contamination of air and inhalable particulate in Rome. Fresen. J. Anal. Chem. 348, 144-147. https://doi.org/10.1007/BF00321618

Van Lieshout, L., Desmedt, M., Roekens, E., De Fré, R., Van Cleuvenbergen, R., Wevers, M. (2001). Deposition of dioxins in Flanders (Belgium) and a proposition for guide values. Atmos. Environ. 35, S83-S90. https://doi.org/10.1016/S1352-2310(01)00094-2

Wang, W., Cui, K., Zhao, R., Zhu, J., Huang, Q., Lee, W.J. (2018). Sensitivity analysis of PM2.5-bound total PCDD/Fs-TEQ content: In the case of Wuhu city, China. Aerosol Air Qual. Res. 18, 407-420. https://doi.org/10.4209/aaqr.2017.11.0507

Wang, Y., Qian, L., Yu, Z., Chun, T., Long, H., Wu, X., Li, J. (2020). Inhibition behavior of PCDD/Fs congeners by addition of $\mathrm{N}$-containing compound in the iron ore sintering. Aerosol Air Qual. Res. 20, 2568-2579. https://doi.org/10.4209/aaqr.2019.12.0660

Wang, Y.F., Hou, H.C., Li, H.W., Lin, L.F., Wang, L.C., Chang-Chien, G.P., You, Y.S. (2010). Dry and wet depositions of polychlorinated dibenzo-p-dioxins and dibenzofurans in the atmosphere in Taiwan. Aerosol Air Qual. Res. 10, 378-390. https://doi.org/10.4209/aaqr.2010.04.0024

Wielgosiński, G. (2011). The reduction of dioxin emissions from the processes of heat and power generation. J. Air Waste Manage. Assoc. 61, 511-526. https://doi.org/10.3155/1047-3289.61.5. 511

Xing, J., Cui, K., Tang, H., Lee, W.J., Wang, L.C., Zhu, J., Huang, Q. (2017). Part II: PM2.5 and polychlorinated dibenzo-p-dioxins and dibenzofurans (PCDD/Fs) in the ambient air of northern China. Aerosol Air Qual. Res. 17, 2010-2026. https://doi.org/10.4209/aaqr.2017.06.0211

Xing, Y.F., Xu, Y.H., Shi, M.H., Lian, Y.X. (2016). The impact of $\mathrm{PM}_{2.5}$ on the human respiratory system. J. Thorac. Dis. 8, E69. https://doi.org/10.3978/j.issn.2072-1439.2016.01.19

Yamasaki, H., Kuwata, K., Miyamoto, H. (1982). Effects of ambient temperature on aspects of airborne polycyclic aromatic hydrocarbons. Environ. Sci. Technol. 16, 189-194. https://doi.org/ 10.1021/es00098a003

Zhou, Z.G., Zhao, B., Qi, L., Xu, P.J., Ren, Y., Li, N., Zheng, S., Zhao, H., Fan, S., Zhang, T., Liu, A.M., Huang, Y.R., Shen, L. (2014). Distribution of polychlorinated dibenzo-p-dioxins and dibenzofurans in the atmosphere of Beijing, China. Aerosol Air Qual. Res. 14, 1269-1278. https://doi.org/10. 4209/aaqr.2013.01.0032 